\title{
Din Eğitiminin Bilimler Arasındaki Konumu: James Michael Lee'nin Din Öğretimi Yaklaşımı Bağlamında Bir İnceleme*
}

The Place of Religious Education Among Sciences: A Study in the Context of James Michael Lee's Approach to Religious Instruction**

\author{
Gurbet KIZILTAN, Sorumlu Yazar, Dr. \\ T.C. Milli Eğitim Bakanlığı, Bursa / Türkiye \\ gurbetk@gmail.com \\ https:// orcid.org/0000-0002-5022-2328
}

ISSN: 1303-880X

e-ISSN: 2667-7504

http://ded.dem.org.tr

Makale Türü / Article Type:

Araştırma Makalesi / Research Article

Geliş Tarihi / Received Date: 05.07.2021

Kabul Tarihi / Accepted Date: 13.11.2021

Yayın Tarihi / Published Date: 25.12.2021

Tr/En: $\operatorname{Tr}$

Intihal / Plagiarism: Bu makale, en az iki hakem tarafindan incelendi ve intihal içermediği teyit edildi. / This article has been reviewed by at least two referees and scanned via a plagiarism software.
Attf/Citation: Kızıltan, G. (2021). Din eğitiminin bilimler arasındaki konumu: James Michael Lee'nin din öğretimi yaklaşımı bağlamında bir inceleme. Değerler Ĕgitimi Dergisi, 19 (42), s. 267-304

https://doi.org/10.34234/ded.962905

* Bu makale Doç. Dr. Turgay Gündüz danışmanlığında hazırlanan doktora tezinden türetildi.

** This article is derived from the doctoral thesis prepared under the supervision of Associate Professor Turgay Gündüz. 
Öz: İlahiyat bilimleri ve sosyal bilimler olmak üzere iki farklı bilimi ilgilendiren konu alanı ile çok içerikli bir boyuta sahip olan din eğitiminin önemli meselelerinden biri söz konusu bilimlerden hangisine ait bir disiplin olduğuna karar vermektir. Yapılan araştırmalarda konu ile ilgili olarak; sosyal bilim yaklaşımı ve teolojik yaklaşım olmak üzere öne çıkan iki yaklaşım tespit edilmiştir. Literatür taraması ve betimsel analize dayanan bu çalışmanın amacı James Michael Lee'nin sosyal bilim yaklaşımı çerçevesinde din eğitiminin hangi bilimler arasında yer alması gerektiği sorusuna cevap aramaktır. Bu amaçla makalede öncelikle Lee'nin yaklaşımında "din"in ve "öğretim”'in mahiyeti, din öğretim süreci ve içeriği incelenmekte daha sonra sosyal bilim yaklaşımının antitezi durumundaki teolojik yaklaşımın mahiyeti, metodolojisi, temel argümanları ve son olarak sosyal bilimsel din öğretiminin teoloji ile ilişkisi ortaya konmaktadır. Araştırma neticesinde, Lee'nin, yaklaşımını teolojik yaklaşım eleştirisi üzerine inşa ettiği, din öğretimini bir ögretme (teaching) biçimi; ampirik bir faaliyet olan öğretmeyi de spekülatif ve bilişsel bir bilim olan teolojinin değil, sosyal bilimin konusu olarak gördüğü tespit edilmiştir. Dolayısıyla öğretme-öğrenme sürecine ilişkin bilimsel verilere dayalı teorik ve pratik deneysel bir çalışma alanı olan ve amacı dinî davranışları kolaylaştırmak olan din eğitimi için en uygun makro teorinin, teoloji değil, sosyal bilim olduğu sonucuna varılmıştır.

Anahtar Kelimeler: Din Eğitimi, Din Öğretimi, Sosyal Bilim, Teolojik Yaklaşım, James Michael Lee.

\section{$\&$}

Abstract: One of the important issues regarding religious education, is how to ground the subject since it is multi-dimensional and concerns two different sciences such as theological and social sciences. In this study; two prominent approaches, namely the social science approach and the theological approach, have been identified. The aim of this study based on literature review and descriptive analysis is to seek an answer to the question of where to ground religious instruction using the framework of the social science approach of James Michael Lee. First of all, the nature of "religion" and "instruction", the religious instruction process, and content were analyzed. Then, the methodology and basic arguments for theological approach, which stands as the antithesis of the social science approach is analyzed, and finally the relationship between social scientific religious instruction and theology is revealed. In conclusion, it has been found that Lee regards religious instruction as a form of teaching, which is an empirical activity and considers teaching as subject of social science, rather 
than theology, which is regraded as speculative and cognitive science. Thus, being grounded in theoretical-practical experimental field of study that is based on scientific data related to teaching-learning process religious education, in term of macro theory is situated mong social sciences.

Keywords: Religious Education, Religious Instruction, Social Science, Theological Approach, James Michael Lee.

(The Extended Abstract is at the end of the article)

\section{Giriş}

Din ve eğitim olmak üzere temel iki içerikten meydana gelen din eğitimi, din boyutu ile ilahiyat bilimlerinin (teoloji); eğitim boyutu ile özelde eğitim bilimlerinin genelde sosyal bilimlerin çalışma alanına girmektedir. Din eğitiminin birden fazla bilimi ilgilendiren konu alanına sahip olması hangi bilimler kategorisinde yer alması gerektiği hususunda tartışmalara konu olmaktadır. Ayrıca çok içerikli boyutu, din eğitiminin kendine özgü araştırma alanını ve bu araştırma alanına uygun bilimsel metotları belirleme, araştırma alanı ile ilgili genel sonuçlara ulaşma, teori ve ilkelerini ortaya koyarken esas alacağı bilimlere karar verme, pratik uygulamalara kaynaklık edecek uygun bir teorik zemin oluşturma ve böylece eğitimin pratik boyutunu bilimselleştirme işini de zorlaştırmaktadır. Din eğitiminin bahsi geçen bu önemli meselelerinin açılığa kavuşturulabilmesi için öncelikle bilimsel bir çalışma alanı olarak kendine özgü kimliğini kazanması, nerede durması gerektiğini ortaya koymak önemlidir. Dolayısıyla din eğitiminin öncelikli meselelerinden biri hangi bilimler arasında yer alması gerektiğine karar vermektir.

Yapılan araştırmalarda, özellikle bilim olarak geç fark edilmesi ve nispeten genç bir bilim dalı olması nedeniyle ülkemizde din eğitiminin bilimler arasındaki yeri meselesinin müstakil bir şekilde ele alınıp detaylı bir şekilde incelenmediği, dolayısıyla bu konuda net bir şekilde ortaya konulmuş farklı yaklaşımlardan da söz etmenin mümkün olmadığı görülmektedir. Bununla birlikte din eğitimi bilimi ile ilgili birkaç eserde bu meselenin detaylı olmaksızın ele alındığı ancak yeterince tartışılmadığı tespit edilmiştir. Osman Pazarlı (Pazarlı, 1967, s. 3, 6) ve Selahattin Parladır (Parladır, 1996, s.13), din eğitimini eğitim bilimleri içinde konumlandırırken; Beyza Bilgin din eğitiminin disiplinler arası bir disiplin olduğuna işaret etmektedir (Bilgin, 2001, s. 1-2). Alman literatüründen hareketle din eğitimi biliminin bilimler arasındaki yeri meselesini Din Ĕgitimi Bilimine Giriş adlı kitabında müstakil bir başlık altında nispeten detaylı bir 
şekilde irdeleyen Cemal Tosun, konu ile ilgili olarak: "Din eğitiminin yeri eğitim bilimleridir", "din eğitiminin yeri ilahiyat bilimleridir", "din eğitimi bilimi disiplinler arası bağımsız bir disiplindir" şeklinde üç yaklaşım tespit etmektedir (Tosun, 2001, s. 38-57). Tosun'a referansla meseleyi ele alan M. Şevki Aydın, din eğitimi bilimini disiplinler arası bir disiplin olarak temellendirmektedir (Aydın, 2017, s. 52, 81, 406). Önemine binaen bu meselenin farklı boyutları ile daha kapsamlı bir şekilde araştırılması gerekli görüldüğünden bu çalışmada literatür taraması genişletilerek konu ile ilgili olarak yurt dışında yapılmış çalışmalara imkânlar ölçüsünde ulaşılmaya çalışılmıştır. Yapılan araştırmalarda, özellikle Batı' da uzun yıllar önce başlayan tartışmalar neticesinde din eğitiminin bilimler arasındaki yeri konusunda çeşitli yaklaşımlar geliştirildiği tespit edilmiştir. Batılı bir din eğitim bilimci olan Lee bu yaklaşımları; teolojik yaklaşım ve sosyal bilim yaklaşımı olmak üzere ikiye ayırmaktadır. Genellikle aşkın Tanrı anlayışını benimseyen teolog ve din eğitim bilimcilerinin benimsediği ve din eğitiminin tüm normlarını ve uygulamalarını teolojiden elde etmesi gerektiğini iddia eden teolojik yaklaşım, dinî öğrenmede Tanrı'nın lütfunu ana faktör olarak gördüğünden süreç içeriğinden ziyade ürün içeriğine odaklanmakta, böylece başta öğrenci olmak üzere öğretim sürecinin diğer önemli değişkenlerini ihmal etmektedir. Din eğitiminin bilimselleşmesi sürecine büyük katkı sunan ve ilk kez sosyal bilim verilerini din eğitimine entegre etmeye çalışan Albert Coe'nun öncülüğünü yaptığı (Coe, 1917), ancak Lee'nin kapsamlı ve sistemli bir makro teoriye dönüştürdüğü sosyal bilim yaklaşımı, din eğitimini sosyal bilimsel bir disiplin olarak konumlandırmaktadır. Lee'nin özellikle teolojik bilim eleştirisi üzerine inşa ettiği bu yaklaşım, sosyal bilimin öğretim etkinliğine yatkınlığı yanında deneysel bir faaliyet olan öğretimin spekülatif ve bilişsel bir bilim olan teolojinin işi olmadığını, din eğitimi için geçerli makro teoriyi teolojinin değil, sosyal bilimin oluşturduğunu, bu yüzden din eğitiminin tüm normlarını öğretim sürecinin deneysel analizinden elde etmesi gerektiğini ve din eğitiminde kilit noktanın öğrencilerde dinî davranışların nasıl daha verimli bir şekilde kolaylaştırılacağını araştırmak ve bu araştırma sonuçlarına göre uygulamada bulunmak olduğunu iddia etmektedir (Lee, 1971a). Din eğitiminin bilimler arasındaki yeri meselesi ile ilgili olarak geliştirilmiş en kapsamlı yaklaşımlardan biri olması, eğitim/öğretim meselesini son derece sistematik bir şekilde incelemesi ve Batılı teolojik din eğitimi yaklaşımlarının etraflı bir kritiği olması açısından bu çalışmada Lee'nin sosyal bilimsel din öğretimi yaklaşımı merkeze alınmıştır.

Bu çalışma, deskriptif bir yöntemle Lee perspektifinden sosyal bilimsel din öğretimi yaklaşımının teorik çerçevesini ortaya koymayı ve bu suretle din eğitiminin bilimler arasındaki konumu meselesine açıklık getirmeyi hedeflemekte- 
dir. Bunun yanısıra sosyal bilim ve teolojik bilim arasındaki temel farklılıkları ortaya koymak ve Lee'nin neden sosyal bilim yaklaşımını teolojik yaklaşıma tercih ettiğini tespit etmek amaciyla teolojinin mahiyeti, teolojik bilimin metodolojisi ve teolojik yaklaşım savunucularının din eğitiminin teolojik bir disiplin olduğuna dair argümanları da incelenecektir. Bu çalışmanın odağında yer almas1 nedeniyle birincil kaynak olarak trilogy olarak isimlendirilen 3 ciltlik temel yapıtı başta olmak üzere Lee'nin eserleri referans alınmıştır. Çalışmada ayrıca teolojik yaklaşımın önde gelen savunucularının görüşlerine de yer verildiğinden onların da bazı eserleri literatüre dâhil edilmiştir. Bu suretle din eğitiminin hangi bilimler kategorisinde yer alması gerektiği sorusunu iki faklı yaklaşım perspektifinden inceleme amaçlanmıştır.

Ülkemizde din eğitiminin bilimler arasındaki konumu meselesi ile ilgili olarak yapılan kapsamlı ilk müstakil çalışma olma özelliği taşıyan bu araştırma, konu ile ilgili olarak yapılacak yeni çalışmalar için soru oluşturma ve meseleye yeni bir perspektifle bakma imkânı sunması açısından önemli bulunmaktadır.

\section{Lee'nin Din Öğretimi Yaklaşımı}

Hristiyan din eğitim camiasında 1960'larda özellikle Katolik din eğitiminde teolojik yaklaşımın önde gelen savunucularından Josef Jungmann ve öğrencisi Johannes Hofinger'in teolojik görüşlerini esas alan "öğretim pratiği teolojik içeriğin hizmetçisidir" din eğitim paradigması hüküm sürmüştür (Newell, 2004, s. 22). Ancak 1962-65 yıllarında gerçekleşen II. Vatikan Konsil'i, sadece teolojik ilkelerin değil, seküler bilime ait bulguların inanan kimsenin inancını daha saf ve daha olgun bir şekilde yaşamasına katkı sağlayacağını vurgulayarak inanç eğitiminde sosyal bilimlerin potansiyel katkısını onaylamıştır (Hobson ve Welbourne, 2002, s. 55-58). Konsil'in bu deklarasyonu, Katolik Kilisesi'nde büyük bir yank1 uyandırmış ve birçok teolog veya din eğitim bilimcinin din eğitim yaklaşımlarını Konsil'in bu kararı ışığında revize etmesini sağlamıştır. Lee'nin sosyal bilimsel din öğretimi yaklaşımı da aslında bu açılımın bir parçasidır (Lee, 1972a, s. 10).

Öğretim tecrübesine dayanarak farklı teorik yaklaşımların din eğitimi açısından uygunluğu ve yeterliliği üzerine incelemelerde bulunan Lee, tespitleri neticesinde sosyal bilimsel din öğretimi yaklaşımının temellerini atmıştır. 19711985 yılları arasında yayımladığı The Shape of Religious Instruction, The Flow of Religious Instruction ve The Content of Religious Instruction adlı üç ciltlik (trilogy) eserlerinde yaklaşımını detaylarıyla ortaya koyan Lee, özellikle seri- 
nin ilk cildi olan The Shape of Religious Instruction ile asırlarca Hristiyan din eğitiminde makro teorik yaklaşım olarak benimsenen teolojik yaklaşıma adeta meydan okumuştur. Bu kitap eleştirmenler tarafından din eğitiminde "devrimci bir çalışma" olarak nitlendirilmiştir (Lee, 1976, s. 253). Bunun temel nedeni, Lee'nin bu kitabında din öğretimi için en uygun makro teorinin teoloji değil, sosyal bilim olduğunu iddia etmesidir (Lee, 1982, s. 122 ve 1996, s. 45). Ayrıca Lee, din öğretiminin ontolojik olarak teolojiden farklı bir alan olduğunu ve bu nedenle teolojik emperyalizmden kurtulması gerektiğini belirten ilk Katolik din eğitimci/eğitim bilimcidir (Lee, 1976, s. 253).

Lee’ye göre din öğretimi teolojik yaklaşım gibi doğasına uygun olmayan yaklaşımlara dâhil edilmek suretiyle bir kimlik krizi ile karşı karşıya bırakılmıştır. Ona göre din öğretim işi, hem sosyal bilim hem de teolojik bilim ile ilişkili olsa da esas itibariyle sosyal bilimsel bir disiplindir. Dolayısıyla acil bir şekilde din öğretiminin sosyal bilim yapısı içindeki ayırt edici kimliğini ortaya koymak gerekir (Lee, 1971a, s. 225).

Öğretme-öğrenme eylemine odaklanan sosyal bilimsel din öğretiminin temel amacı öğrencide dinî davranışları etkili bir şekilde kolaylaştırmaktır. Dinî davranışları kolaylaştırmak amacıyla sosyal bilim verilerini merkeze alan Lee'nin din öğretim yaklaşımının ayırt edici özelliği sosyal bilim ilkelerine ve metodolojisine sıkı sıkıya bağlı olmasıdır (Lee, 1971a, s.184-216). Sosyal bilimin temel özelliği, masa başı bir metodolojiden ziyade deneysel, objektif ve nicel verilere dayanmasıdır. Öğretim işinde sosyal bilim verilerini normatif olarak kabul eden sosyal bilimsel din öğretimi, ampirik olarak gözlemlenmiş ve doğrulanmış olgulardan elde edilen yasalara dayanarak dinî davranışları anlamayı, açıklamayı ve öngörmeyi amaçlar (Burgess, 1975, s. 127-128) ve deneyim, doğrulama, öngörme, değerden bağımsız olma, kolaylaştırma, davranış değişikliği, öğrenme ortamını şekillendirme vb. ile ilgilenir (Coughlin, 1981, s. 131).

Sosyal bilim de her bilim gibi kendi teknik terminolojisine sahiptir. Yaklaş1mında davranış, değişken, öngörü, doğrulama vb. sosyal bilim terimlerini esas almakla birlikte Lee kendine has bir terminolojiye de sahiptir. Lee zaviyesinden bazı kavramlara ne tür anlamlar yüklenildiğini bilmek, yaklaşımının doğru anlaşılması açısından önemlidir.

\section{Lee'nin yaklaşımında temel kavramlar}

Lee'nin yaklaşımının merkezinde din ögretimi terkibini oluşturan din ve öğretim kavramları ile öğretim kavramıyla yakından ilişkili olan ögrenme, ögret- 
me, eğitim ve davramış kavramları yer almaktadır. Bu kavramların Lee cephesinden nasıl anlaşıldığını bilmek önemlidir. Çünkü Lee'nin teolojik yaklaşıma yönelik eleştirilerinin temelinde bu yaklaşımın özellikle öğrenme ve öğretmeyi ele alış biçimi yer almaktadır.

Din terimini, her türlü ilahi yönelimli dine atıfta bulunmak için kullanan ve işlemsel olarak tanımlayan Lee'ye göre din, bir insanın Tanrı ile yaşadığı ilişkinin bütününü ifade eden (Lee, 2000, s. 256) inanç, bilgi, deneyim, duygu ve pratiklerin bir karışımı, kişisel olarak yaşanan holistik bir hayat tarzıdır (Lee, 1982, s. 107). İşlemsel tanım, dini, dinî olarak nitelendirilebilecek belirli davranışlar cinsinden tanımlar ve herhangi bir belirsizlik içermez. Ayrıca işlemsel tanım, biliş gibi herhangi bir insan işlevini vurgulamak yerine, kişiyi bilişsel, duyuşsal ve hayat tarzı gibi tüm işlevleri ile bir bütün olarak ele alır (Lee, 1985a, s. 21). Buna göre Lee'nin işlemsel din tanımı, dinin bütünüyle insan deneyimi olduğuna işaret etmektedir. Dolayısıyla bütünseldir çünkü varoluşsal olarak insan varlığının tüm alanlarını içerir ve bütünleştirir. Ayrıca bu tanım kişiseldir çünkü dini, ilişki halindeki bir kimsenin etkinliği olarak görür. Son olarak bu tanım deneyimseldir çünkü dini doğrudan insanın deneyim alanına yerleştirir (Lee, 1985b, s. 650). Yaklaşımında işlemsel tanımı esas almak suretiyle dinin bütünüyle bir insan etkinliği olduğunu vurgulayan Lee'nin bu tanımı sosyal bilim yaklaşımının nasıl bir din öğretimi öngördüğünü anlamak açısından oldukça önemlidir.

Lee’ye göre öğretimin doğası öğrenmeye bağlı olduğundan öğretim ancak öğrenme açısından doğru bir şekilde tanımlanabilir. Çünkü öğretim, başka bir kişide öğrenmeye neden olmak, öğrenmeyi kolaylaştırmaktır (Lee, 1973a, s. 57). Lee'ye göre öğrenme ise bir inşa etme, bireyin davranış değişikliklerini gözlemlemekten elde edilen bir çıkarım (Burgess, 1996, s. 212), davranıştaki herhangi bir değişikliği belirtmek için kullanılan bir kavramdır (Lee, 1973a, s. 59). Öğrenme aynı zamanda gözlemlenen davranışta değişiklik meydana gelip gelmediğini saptayan bir ölçüttür (Lee, 1978a, s. 40).

Öğrenmeyi davranış değiş̧ikliği olarak tanımlayan Lee'ye göre davranış, hem açıktan yapılan fiziksel eylemleri hem de içsel psikolojik ve duygusal süreçleri ve örtük zihinsel faaliyetleri içine alan bir kavramdır (Lee, 1971a, s. 55). Sosyal bilimciler genel olarak insan davranışlarını bilişsel, duyuşsal ve psikomotor olmak üzere üçe ayırırlar. Lee bu davranışlara, bilişsel, duyuşsal ve psikomotor davranışlarının belirli bir davranış kalıbı içinde kaynaşıp bütünleşmesi sonucunda ortaya çıkan ve hayat tarzı davranışı (life-style behavior) olarak 
adlandırdığ dördüncü bir davranış türünü daha ilave eder (Lee, 1981, s. 27 ve 1978a, s. 40). Yaklaşımında görünen-haricî davranışlara odaklanan Lee, yaşam tarzı davranışlarını oldukça önemli bulur. Çünkü bu davranışlar deneysel olarak test edilebilir ve doğrulanabilir (Lee, 1970a, s. 13). Buna karşıllk gözlenemeyen veya herhangi bir ölçüm aleti ile ölçülemeyen örtük veya içsel süreçlerdeki değişimi değerlendirmek kolay değildir (Lee, 1971a, s. 55) . Lee'nin davranış tanımı, sosyal bilim metodolojisine bağl11ı̆ıını ve din öğretim yaklaşımının bir hayat tarzı olan dinin öğretimine imkân vermesi açısından önemlidir. Çünkü örtük veya içsel dinî davranışları öğretmek kolay değildir. Ayrıca öğrencinin bu davranışları kazanıp kazanmadığını tespik etmek oldukça güçtür. Lee'nin yaklaşımında dinî davranış belirsiz veya gizemli bir fenomen değil; tanımlanabilir, gözlenebilir ve ölçülebilir dolayısıyla öğretilebilir bir fenomendir.

Teolojik yaklaşım ve sosyal bilim yaklaşımı arasındaki temel farklılıklardan biri öğrenme hadisesine yaklaşım biçimidir. Genel olarak teolojik yaklaşım savunucuları, kişiyi harekete geçiren ve öğrenmenin gerçekleşmesini sağlayan temel etkenin Kutsal Ruh olduğunu, bir başka deyişle öğrenmenin ilahi bir lütufla gerçekleştiğini, dolayısıyla dinî öğrenmenin diğer öğrenme türlerinden farklı olduğunu iddia ederler (Lee, 1996, s. 55). Lee, araştırma verilerine dayanarak (Goldman, 1964, s. 1-9) tüm öğrenme türlerinin aynı olduğunu, dolayısıyla dinî öğrenmenin diğer öğrenme türlerinden farklı olmadığını belirtir (Lee, 1978a, s. 50). Çünkü din, hayatın bir parçasıdır, dolayısıyla dinin öğrenilmesi bir bireyin kişisel yaşamının bir parçası olup, kişinin genel öğrenme sürecinden ayrllabilecek bir şey değildir (Lee, 1988a, s. 167). Ona göre teolojik yaklaşım savunucularının dinî öğrenmeyi teslis inancının bir gereği olarak Kutsal Ruh'un gizemli etkinliğine dayandırmaları ve öğrenme sürecini yöneten yasaları görmezden gelmeleri makul değildir. Lee, içkin Tanrı'nın, öğrenme-öğretme de dâhil insani her süreçte kendi koyduğu yasalara göre yer aldığını, din de dâhil her türlü öğretme-öğrenmenin bu yasalara göre meydana geldiğini (Lee, 1973a, s. 150), sosyal bilimlerin öğretme ve öğrenmenin doğasına ilişkin temel ilkeleri, olguları keşfetmek suretiyle din öğretimine katkı sağladığını ve din öğretmenin bu olgu ve ilkeleri pedagojik faaliyetinin dokusuna dâhil etmesi halinde Kutsal Ruh'un etkisinin kendisini göstereceğini belirtir (Lee, 1988a, s. 166-167).

Lee'nin öğrenme ile ilgili görüşlerinin şekillenmesinde Thomastic realizm de büyük bir etkiye sahiptir. Katolik din eğitimine önemli katkılar sunan St. Thomas, insanın ruh ve bedenden oluştuğunu, insanoğlunun her eyleminde bu iki ilkenin eşzamanlı olarak hareket ettiğini savunur (Küken, 1996, 203-204). Buna 
göre Lee, öğrencinin doğaüstü bir boyuta da sahip olduğunu, doğal ve doğaüstü boyutlarının bir birey olarak öğrencinin varlığında ayrılmaz bir şekilde iç içe geçtiğini belirtir (Lee, 1963, s. 122). Lee'nin sosyal bilimsel yöntemler kullanılarak dinî davranışın tespit edilebileceği ve değiştirilebileceği konusunda 1srar etmesinin temelinde, insanın doğal ve doğaüstü boyutları arasında ayrılmaz yapısal bir ilişki olduğu görüşü yer almaktadır. Çünkü sosyal bilimsel din öğretimi, dinî öğrenmenin teolojik yaklaşım savunucularının iddia ettiği gibi kişiliğin doğaüstü, gizemli boyutuna göre değil, aksine öğrencinin kişilik yapısının bütünlüğüne göre meydana geldiği, dolayısıyla etkili din öğretiminin öğrencinin kişilik yapısındaki bu bütünlüğü tanıması, koruması ve bu bütünlüğe göre meydana gelmesi gerektiği ilkesini esas almaktadır.

Lee'ye göre ögretim (instruction), ögretme (teaching) ile eşanlamlıdır ve öğrenmeyi daha hızlı gerçekleştirmek için eğitsel süreçleri olabildiğince etkin hale getirmek, öğrenme kazanımlarını bireyin yaşam tarzına kalıcı bir şekilde transfer etmek için öğrenme ortamını yapılandırmak suretiyle (Lee, 1971a, s. 8) öğrenme kazanımlarının kolaylaştırıldığı maksatlı eğitim sürecini ifade etmektedir (Lee, 1978a, s. 41). Ayrıca öğretim, öğretme-öğrenme süreci ile ilgili bilimsel veri, yasa ve teorilere dayalı (Lee, 1993a, s. 33) deneysel bir faaliyet, bir bilimdir (Lee, 2000, s. 253). Bilim olarak öğretim üç temel fonksiyona sahiptir. Bunlar; açılklama, öngörü ve öğretim aktivitesini doğrulamadır. Bilim olarak öğretim, din eğitimcisine öğretim aktivitesine ilişkin temel açıklamalar sunar. Böylece eğitimci belli bir pedagojik yöntemin muhtemel başarı veya başarısızlığının nedenlerini bilebilir. (Lee, 1992, s. 168-169 ve 1993b, s. 190). Bilim olarak öğretim, eğitimciye güvenilir bilgi akışı sağlar böylece eğitimci hangi pedagojik yöntemin hangi koşullarda işe yarayıp yaramayacağı konusunda öngörüde bulunabilir (Lee, 1972b, s. 43-54). Öngörü olmaksızın öğretim gelişigüzel bir aktiviteye dönüşür. Lee'nin yaklaşımında öngörü, öğretme-öğrenme dinamiğinin merkezinde yer almaktadır. Hatta Lee, öngörünün, din öğretiminin sosyal bilimin mi yoksa teolojik bilimin mi bir disiplini olduğunu saptamada önemli bir ölçüt olduğunu belirtir (Lee, 1971b, s. 112-113). Çünkü teolojik yaklaşımda Kutsal Ruh'un eylemlerini öngörmek imkânsızdır. Lee'ye göre doğrulama; hakikati tespit etme, kesinlik oluşturma ve gerçekliği tesis etme işlemidir (Lee, 1971a, s. 121-122). Lee'nin yaklaşımında açıklama, öngörü ve doğrulama aslında sosyal bilimin metodolojisini tanımlamaktadır.

Lee'ye göre öğretim, aynı zamanda bir sanat, bilimsel olarak doğrulanmış yasa, olgu ve teorilere dayalı olarak performans sergilemektir (Lee, 1990a, s. 293). Çünkü öğretim, pedagojik eylemin yaratıcılığını (sanat) ve geçerliliğini 
(bilim) muhafaza edecek şekilde hem sanatsal hem de bilimsel unsurlar kullanır (Baatuma, 1986, s. 132). Bir sanat olarak öğretim, istendik sonuçları doğuracak şekilde bilimsel verilerin ve ilkelerin ustaca, artistik ve dinamik bir form içinde ve maksatlı olarak biçimlendirilmesi/yapılandırılmasıdır (Lee, 1973a, s. 215-22 ve 1993b, s. 188).

Öğretim (instruction) ve eğitim (education) arasında parça-bütün ilişkisi olduğunu belirten Lee'ye göre öğretim özetle; bir amaca yönelik olarak gerçekleștirilen bir eğitim şeklidir ve gayesi öğrenmeyi, hususî olmayan kaynaklardan ve ortamlardan elde edilen benzer durumdaki öğrenmelerden daha etkili, daha hızlı ve daha kolay gerçekleştirmek, işi rastlantıya bırakmamaktır (Lee, 1982, s. 111-112).

Sosyal bilim yaklaşımı ile ilgili yazdığı ilk eserlerinde din eğitimi (religious education) terimini kullanan, ancak yaklaşımına ilişkin görüşlerini kapsamlı ve sistemli hale getirdiği sonraki çalışmalarında, özellikle trilogy ve sonrasında yazdığ 1 eserlerde, din öğretimi (religious instruction) terimini tercih eden Lee'ye göre bu terim, sosyal bilim yaklaşımının mahiyeti ve amaçları açısından daha uygun ve daha kullanışlıdır (Lee, 1988c, s. 34). Lee'nin bu terimi tercih etmesinin temelinde eğitim ve öğretim kavramlarına yüklediği anlamlar yer almaktadır. Lee, eğitimi, öğretimi de içine alan daha genel; öğretimi ise daha özel bir kavram olarak ele almaktadır. Dolayısıyla teorisinin odağında daha geniş bir kavram olan din eğitimi değil, din öğretimi vardır.

\section{Din öğretiminin mahiyeti}

Dinî davranışların çok faklı etkenler aracılığı ile ortaya çıktığının farkında olan Lee, din öğretimi terimi ile dikkatini bu faktörler içerisinde kontrol edilebilir olanlara yöneltmektedir (Newell, 2004, s. 27). Çünkü öğretim, tesadüfi öğrenmeyi değil, planlı ve maksatlı eğitimi ifade etmektedir (Lee, 1983b, s. 2 ve 2000, s. 243). Buna göre din öğretimi, formal-informal yapılandırılmış herhangi bir ortamda bir amaca yönelik olarak gerçekleştirilen din eğitim türünü ifade etmektedir (Lee, 1995, s. 536). Dolayısıyla okul ile sınırlandırılmaksızın öğrenme kazanımlarını üretmek için planlanmış/yapılandırılmış her türlü kolaylaştırma faaliyeti din öğretimidir (Lee, 1970a, s. 12 ve 1993a, s. 33).

Öğretimi bilim ve sanat olarak tanımlayan Lee, din öğretimini de öğretme-öğrenme yasalarına dayalı bilimsel ve sanatsal bir faaliyet olarak nitelemektedir (Lee, 2000, s. 252-253). Çünkü din öğretimi temel formunu ve uygulamaya yönelik ilkelerini öğretim sürecinin doğasında yer alan ve öğretim sürecine yön veren ilkelerden alır (Lee, 1978a, s. 42). Öğretim süreçlerinin icrası ise bir sa- 
nattır. Bilimsel açıdan din öğretimi, dinî öğrenmenin nasıl kolaylaştırıldığg ve öğrencinin davranışının dinî doğrultuda nasıl değiştirildiği konusunda sürekli olarak sosyal bilim bulgularına ve ilkelerine dayanır. Sanatsal bir faaliyet olarak din öğretimi ise fiili bir beceri ve öğrenme kazanımlarını kolaylaştırma yeterliliğinden oluşmaktadır. Buna göre din öğretmeni yalnızca din öğretim bilimine dayanmakla yetinmemeli, dinî davranışları kolaylaştırmak için gerekli becerilere de sahip olmalidır (Lee, 1971a, s. 51).

Lee'nin yaklaşımının temel ilkelerinden biri din öğretiminin bir kolaylaştırma süreci olmasıdır. Kolaylaştırma, "öğrenme koşullarının, bireyin gelişimsel olarak bulunduğu düzeyde öğrenebileceklerini öğrenmesini mümkün kılacak şekilde, bilinçli olarak düzenlenmesidir.” (Lee, 1971a, 49). Kolaylaştırma sürecindeki en önemli değişken, öğrenme ortamını bilinçli bir şekilde yapılandırmak suretiyle davranış değişikliğine neden olan öğretmendir (Lee, 1970a, s. 12). Lee, kolaylaştırma sürecinin sosyal bilimlere has bir aktivite olduğunu, öğrenmeyi Tanrı'ya havale eden teolojik yaklaşımın davranış değişikliğini kolaylaştırmak için gerekli donanıma sahip olmadığını, bu yüzden teolojik bilim savunucularının sosyal bilimin kolaylaştırma sürecindeki rolünü yeterince önemsemediklerini, bu durumun da din öğretimi açısından olumsuz sonuçlar doğurduğunu belirtir (Lee, 1971a, s. 209).

Din öğretimi faaliyetinde kolaylaştırılması istenen öğrenme kazanımları davranışsal sonuçlardır (Lee, 1970a, s. 12). Lee, din öğretiminin öğrencinin bilişsel, duyuşsal, ürün ve süreç içeriklerinin tamamını, bir başka deyişle hem dâhilî hem de haricî davranışlarını bir bütünlük içinde ve eşzamanlı olarak değiştirmeyi hedeflemesi gerektiğini belirtir. Lee'nin yaklaşımında tüm bu içerikler Hristiyan yaşam tarzını veya dinî hayatı oluşturur (Lee, 1971a, s. 56, 212-213). Dolayısıyla din öğretiminin en temel görevi öğrencide dinî hayatı kolaylaştırmak veya dinî doğrultuda davranış değişikliği meydana getirmektir (Lee, 1970a, s. 12 ve 1971a, s. 55). Çünkü gerçek öğrenme davranış değişikliği ile sonuçlanır, davranışta değişiklik yoksa öğrenme de yoktur (Cullen, 2005, s. 176). Dolay1sıyla Lee'nin yaklaşımında bir bireyin davranışlarının değiştirilmesi öğrenmeyi ifade etmenin işlevsel bir yoludur (Lee, 1971a, s. 212).

Sosyal bilimsel din öğretiminin önemli odak noktaları vardır. Bunlardan biri, Lee tarafından kavramsallaştırılan Hristiyan yaşamıdır (Burgess, 1974, s. 296 ve 1975, s. 132). Yaşamın dinî boyutunu ifade eden Hristiyan yaşamı (Christian living), birbiriyle uyumlu, birbirini tamamlayıcı ve kişinin kendisini gerçekleştirmesini mümkün kılarak içindeki potansiyeli ortaya çıkarmasını sağlayan ge- 
lişimsel beş boyuttan oluşmaktadır. Bunlar; ideolojik (dinî inanç) boyut, ritüel (ibadet ya da dinî uygulamalar) boyutu, entelektüel (dinî bilgi ve anlama) boyut, tecrübe (dinî duygu) boyutu ve bütün bunların sonunda ortaya çıkan etki (dinî davranış) boyutudur (Glock, 1962, s. 98-110). Lee’ye göre dinî yaşam, kişinin bu beş boyutun tamamını uyum içinde harekete geçirmesidir. Bu boyutların hiçbiri tek başına dinî yaşamı oluşturamaz (Lee, 1971a, s.11).

Sosyal bilimsel din öğretiminin önemli bir diğer odak noktası dini öğrenmede önemli bir role sahip olan deneyimdir. Çünkü bu yaklaşıma göre dinin kendisi bir deneyim, aslında yaşamı deneyimleme biçimidir (Cullen, 2005, s. 174). Lee, bir kimsenin hâlihazırdaki kişisel deneyiminin öğretmen tarafından doğru bir şekilde yönlendirilmesi durumunda bu kimsenin hayatı daha anlamlı bir şekilde yaşamasının mümkün olacağını belirtir. Ona göre teolojik yaklaşım, öğrenme için temel bir rehber olan deneyimi aktarılacak teolojik içerik için bir araç olarak kullanmakta ve deneyimin eşsiz eğitici zenginliğini kavramakta son derece başarısız olmaktadır (Merry, 2000, s. 88).

Lee, din öğretim sürecinde; amaç, konu, öğretmen, öğrenci, ögrenme ortamı ve değerlendirme olmak üzere altı temel değişken olduğunu (Lee, 1972c, s. 370-371), bu değişkenleri maksatlı bir şekilde düzenlemek suretiyle din öğretmeninin öğrenme kazanımlarını ortaya çıkaracağını, ayrıca din öğretimine uygun makro teorik yaklaşımın, bu temel değişkenleri içerip içermediğini ve bu değişkenler arasındaki ilişkiyi ayrı ayrı ve bir bütün olarak açıklayabilme, öngörebilme ve doğrulayabilme yeterliliğini test etmek suretiyle belirlenebileceğini belirtir (Lee, 1973a, s. 151 ve 1996, s. 49).

Yaklaşımında amaca yaptığı vurgu ile öne çıkan Lee, din öğretiminin sonuçlarının "din" olmasını ister. Buna göre din öğretiminin temel amacı, dinî davranışları (Lee, 1978a, s. 53), Lee'nin terminolojisi ile Hristiyan yaşamını kolaylaştırmaktır (Burgess, 1974, s. 296). Teolojik eğitimin amacı bireyin bilinçli bir şekilde kilise cemaati içinde sosyalleşmesini sağlamaktır. Bu, bireyin davranışlarının mensubu olduğu cemaat tarafından kontrol edilmesi ve sınırlandırılması, dolayisıyla bireyin manipüle edilmesi ve kişisel büyüme potansiyelinin ihmal edilmesi anlamına gelmektedir (Poochigian, 1986, s. 112-113). Çünkü teolojik eğitim amaçları bakımından GCD ve Roman Katolik Kilisesi'nin diğer resmi beyanlarına bağlıdır (Lee, 1980, s. 344-345). Lee'nin yaklaşımında öğretim sürecinin önemli bir diğer değişkeni öğretilen şey (konu) veya öğrenme içeriğidir. Sosyal bilim yaklaşımı, din öğretiminde asıl konunun, din öğretimi sürecinde öğretilebilen-öğrenilebilen "din” olduğunu söyler. Teolojik yaklaşım savunucu- 
ları ise din öğretiminde asıl konunun teoloji olduğunu ileri sürerler (Lee, 1982, s. 132 ve 1993 a, s. 33).

Sosyal bilim yaklaşımı din öğretim işinde öğretmene büyük bir sorumluluk yükler. Çünkü öğretmen, bir amaca yönelik olarak öğrenme ortamını yapılandırmak suretiyle öğrenmeyi kolaylaştıran en yetkin kimse, öğrencinin dinî hayatını etkilemek suretiyle davranışını değiştiren bir uzmandır (Lee, 1970b, s. 67-69 ve 1995, s. 554). Din öğretiminde öğretmene çok az önem atfeden teolojik yaklaşım, genellikle bir çocuğun eğitiminde öğretmenin daima Kutsal Ruh'a tabi olduğunu çünkü din öğretiminin öğretmen ve öğrenci arasında değil de Tanrı ve öğrenci arasında meydana gelen doğaüstü ve gizemli bir olay olduğunu ileri sürmektedir (Moran, 1966, s. 116-117). Ancak Lee, din öğretiminin gizemli bir deneyim olmadığını, her şeyden önce, öğrenme kazanımlarını ortaya çıkaracak şekilde maksatlı olarak yapılandırılmış öğrenme ortamında öğrenci ve diğer değişkenler arasında meydana gelen bir etkileşim olduğunu belirtir (Lee, 1971a, s. 209).

“Tüm öğrenme, öğrencinin moduna göredir” (Lee, 1963, s. 111-143) ilkesini esas alan sosyal bilimsel din öğretiminin merkezinde ve hedefinde bir birey olarak öğrenci yer almaktadır. İnsani gelişime, öğrencinin kişiliğinin bütünlüğüne odaklanmak ve olabileceği her şey için imkânlar sağlamak din öğretiminde hayati derecede önemlidir (Lee, 1971a, s. 34). Lee'nin bir birey olarak öğrenciyi din öğretim sürecinin odak noktalarından biri olarak görmesinin temel nedeni Hristiyan din eğitiminde uzun yıllar benimsenen Sadakat yaklaşımı (fidelity approach) ve bunun pratik bir sonucu olan Munich metodunun bireyi ihmal etmesi ve sadece ürün içeriğine odaklanmasıdır. Bunun yanı sıra aşkın Tanrı anlayışını benimseyen teolojik yaklaşım savunucuları, öğrenciyi genellikle Kutsal Ruh tarafindan öğretilenlere inançla cevap verebilecek alt tür sorumlu bir varlık olarak görmektedirler (Lee, 1996, s. 54). Bu yüzden teolojik yaklaşım savunucularının büyük bir çoğunluğu dinî öğrenmenin diğer öğrenme türlerinden farklı olduğunu çünkü dinî öğrenmenin insanın gayretinden ziyade Tanrı'nın lütfu ile gerçekleştiğini, dolayısıyla bilimsel araştırmalara konu olamayacağını iddia etmektedirler (Knox, 1976, s. 71). St. Thomas'a referansla Lee, insanoğlunun hem doğal hem de doğaüstü boyutlarının bir birey olarak öğrencinin varlığında iç içe geçtiğini, dolayısıyla dinî öğrenmenin, kişiliğin mistik veya doğaüstü boyutuna göre değil, bir bütün olan bireyin kişilik yapısına göre meydana geldiğini belirtir (Lee, 1963, s. 120-128). Bu bağlamda sosyal bilimsel din öğretimi, öğrenciye ve öğrenme sürecine, öğrencinin aslında bir insan olarak gerçekte 
nasıl bir işlev gördüğ̈̈ ve öğrenenin aslında nasıl öğrendiği zaviyesinden bakmak suretiyle teolojik yaklaşımdan ayrılmaktadır.

Sosyal bilimsel din öğretimi, sosyal bilim verilerine dayalı yapılandırılmış öğrenme ortamının üzerinde önemle durur. Bunun temel nedeni Lee'nin vahyi tarihsel bir fenomen olmaktan ziyade insanoğluna özgü sürekliliği olan bir deneyim olarak görmesidir (Lee, 1971a, s. 16). Buna göre deneyim, ilahi vahyin izharıdır. O halde öğretmeninin görevi Tanrı'nın vahyinin bilinçli ve anlamlı bir şekilde davranış tarzına dâhil olmasını sağlayacak şekilde öğrencinin deneyimlerini yapılandırmaktır (Knox, 1976, s. 103). Öğrenme ortamı veya din sınıfı, Tanrı ile irtibat kurmayı kolaylaştırmayı amaçlarsa Tanrı kendisini deneyimler aracıllğıyla ifşa eder. Öğrenci buna göre hareket ettiğinde de Hristiyan yaşam tarzını inşa etmiş̧ olur (Lee, 1971a, s. 16). Bu yüzden Lee, öğrenme ortamını veya sınıfı Hristiyan yaşamı için bir laboratuvar olarak kavramsallaştırır. Hristiyan yaşamı için laboratuvar, aslında öğrencilerin bütünsel olarak dinî yaşam tarzı arayışlarına girdikleri şartlar bütünüdür (Lee, 1985a, s. 34). Böyle bir ortam, bireyin kendi gelişim özelliklerine göre öğrenmesine olanak sağlar (Burgess, 1974, s. 310). Teolojik yaklaşım savunucuları, dinî öğrenmede ana faktörün Tanrı'nın lütfu olduğunu düşündüklerinden ortam değişkenine de önem vermezler (Lee, 1995, s. 558). Onlara göre öğrenme ortamının yapılandırılması yani kolaylaştırma Tanrı'ya müdahale etmek veya Tanrı'yı kontrol etmek ve öğrenciyi manipüle etmektir. Lee, kolaylaştırma sürecinde Tanrı'nın eylemlerine müdahale etmenin söz konusu olmadığını, ayrıca kontrol edilen şeyin öğrenme ortamı olduğunu, dolayısıyla tüm süreçlerde yer alan içkin Tanrı'nın yapılandırılmış öğrenme ortamında, insanın fitratına göre hareket etmek suretiyle etkili bir şekilde faaliyette bulunabileceğini iddia eder. Ayrıca Lee, öğrenme hedeflerini öğrenci ile ortaklaşa hazırlamak suretiyle öğretmenin öğrenciyi manipüle etmekten sakındığını belirtir (Knox, 1976, s. 73,105).

Sosyal bilimsel din öğretimi, değerlendirmeyi din öğretiminin tamamlayıc1 bir boyutu olarak görür. Çünkü değerlendirme, hem öğrencinin öğrenip öğrenmediğini hem de onun neyi, ne ölçüde öğrenmiş olduğunu, nasıl öğrendiğini keşfetmeye yardımcı olur. Dolayısıyla öğretme-öğrenme sürecinde değerlendirme, hem eğitimciye hem de öğrenciye kendi ilerleyişi hakkında somut bilgi vermesi açısından çok önemli bir role sahiptir (Lee, 1971a, s. 54 ve 1982, s. 140). Lee’ye göre öğrenci öğrenmesinin bir amaca yönelik olarak değerlendirilmesi, spekülatif kanıtlardan ziyade bilimsel temellere dayanmalı, olumlu ve sürekli olmalıdır. Ayrıca değerlendirmede amaç, yalnızca nihai öğrenme ka- 
zanımlarını ölçmek değil, öğrencinin istenilen hedeflere ulaşmasına yardımcı olmak olmalıdır (Burgess, 1974, s. 311 ve 1996, s. 218-219). Yani öğrenmenin değerlendirilmesi, öğretimin son noktası olarak değil, öğretim sürecinin bir parçası olarak düşünülmelidir (Lee, 1978b, s. 28). Lee, bu husustaki görüşlerini şöyle özetler: "Sınav, öğretimi takip etmez. Sınav, öğretimin ayrılmaz bir parçasıdır." (Lee, 1963, s. 438-39). Teolojik yaklaşım savunucuları değerlendirmeye gereken önemi vermez, hatta din eğitiminin verimliliğini bilimsel metotlar kullanarak değerlendirmekten bilhassa kaçınırlar. Bunun çeşitli nedenleri vardır, ancak temel neden din eğitiminin gerçek sonuçlarının, Kutsal Ruh'un gizemli hediyeleri olduğunu bu yüzden değerlendirmeye tabi tutulamayacağını düşünmeleridir (Knox, 1976, s. 106). Lee'ye göre din öğretiminin sonuçları gizemli ise, eğitimcinin uyguladığı pedagojik işlemlerden herhangi birinin başarılı ya da başarısız olduğunu ya da öğrencinin herhangi bir kazanımı elde edip etmediğini bilmesi veya öngörüde bulunması mümkün olamaz (Lee, 1982, s. 140-141 ve 1996, s. 57-58). Değerlendirmeyi bir zorunluluk olarak gören Lee, din öğretiminin gelişimi için gizlilikten arındırılması gerektiğini, çünkü dinî davranışın belirsiz, gizemli bir fenomen olmadığını, aksine dinî davranışın tanımlanabilir, gözlemlenebilir ve ölçülebilir olduğunu ileri sürmekte (Lee, 1972c, s. 371-373 ve 1985a, s. 30) ve söz konusu iddiasını hem dinî kaynaklar hem de bilimsel verilerle desteklemektedir (Peabody, 1909, s. 3).

Lee'nin yaklaşımında din öğretiminin temel görevi öğretme-öğrenme sürecini bilimsel olarak araştırmak ve incelemektir. Ona göre öğretme-öğrenme sürecinde yer alan değişkenleri sistematik ve kapsamlı bir şekilde incelemeyen, bu değiş̧kenler arasındaki etkileşimi araştırmayan, öğretme-öğrenme sürecini açıklamayan ve doğrulamayan teolojik makro teorinin din öğretiminde uygulanabilirliği söz konusu olamaz. Çünkü din öğretiminin özü öğretmedir. Öğretme ise bilişsel bir bilim olan teolojinin değil, sosyal bilimin işidir.

Sosyal bilimsel din öğretimi metot-içerik düalizmini reddeder. Bu husus, Lee'nin yaklaşımını teolojik yaklaşımdan ayıran önemli farklardan biridir. Metodun büyük ölçüde içerik tarafından belirlendiğini iddia eden teolojik yaklaşım savunucuları, metot ve içeriği bir birinden tamamen ayırmak suretiyle metot-içerik düalizmini benimsemektedirler. Çünkü onlara göre içerik (mesaj) doğaüstü bir şekilde verilmiştir, dolayısıyla öğretmen yöntemden ziyade içerikle ilgilenmelidir (Knox, 1976, 69-70). Onlara göre din eğitiminin görevi teolojik bilgiyi olabildiğince orjinaline sadık kalarak öğrenciye aktarmaktır (Lee, 1970b, s. 56-57 ve 1995, s. 546). Bu bağlamda teolojik yaklaşımın önde gelen 
savunucularından Hofinger, din eğitimi pratiğini, teolojik içeriği öğrencilere aktarma yolundan ibaret görürken (Hofinger, 1961, s. 62-65); Josef Goldbrunner din eğitiminin, teolojik mesajın hizmetçisi olarak düşünülebileceğini belirtir (Goldbrunner, 1961, 112-113). Lee'ye göre ise din öğretim camiasında yaygın olarak kabul gören metot-içerik ikilemi tamamen yanlıştır (Lee, 1972c, s. 369-370). Lee'nin metot-içerik düalizmini niçin reddettiğini anlayabilmek için öncelikle metot ve içerikten ne anladığını ortaya koymak önem arzetmektedir.

\section{Din öğretiminin içeriği}

İçerik genel olarak öğretmen tarafından öğretilen ve öğrenci tarafında öğrenilen çok boyutlu bir gerçeklik olarak tanımlanır (Lee, 1985b, s. 8). Din öğretimi için en uygun içerik Lee tarafından tanımlanan din ögretim ameliyesidir. Biçimsel olarak bakıldığında din öğretim ameliyesinin din ve ögretim olmak üzere temel iki içerikten oluştuğu görülmektedir. Lee'nin özsel içerik olarak adlandırdığı ve bir kavramsallaştırmadan ziyade yaşanan bir deneyim olan din, din öğretiminin öğrenme konusunu; yapısal içerik olarak kavramsallaştırdığı öğretim ise din öğretim sürecini veya pratiğini (metot) ifade etmektedir (Lee, 1983a, s. 301 ve 1983b, s. 33 ve 1988a, s. 153). Her türlü din öğretim faaliyeti bu iki temel içerikten oluşur. Otonom bir varlığa sahip olmayan bu iki içerik, din öğretimi ameliyesinde varoluşsal olarak kaynaşarak din öğretimi için en uygun içeriği oluşturur (Lee, 1985b, s. 8 ve 1992, s. 177). Buna göre Lee'nin din öğretim yaklaşımında özsel ve yapısal içerik arasında herhangi bir düalizm söz konusu değildir. Çünkü Lee'ye göre yapısal içerik yalnızca öğretim pratiği (metot) olmadığı gibi özsel içerik de yalnızca öğretilen şey değildir. Yapısal içerik aynı zamanda öğrenilen şeydir. Çünkü bir içeriğin öğretilme şekli (metot) öğretilen içeriği büyük oranda etkiler ve değiştirir. Dolayısıyla içerik-içerik ikilemi söz konusu olamaz (Lee, 1983b, 33-34).

Din öğretiminin yapısal içeriği. Din öğretimi pratiğinin, yalnızca içerik aktarma görevini yerine getirme yöntemi olarak değil, önemli bir içerik öğesi olarak görülmesi gerektiğini belirten (Burgess, 1974, s. 304) Lee, öğretim çalışmalarını verimli kılmak için öğretim sürecine dair bir taksonomi oluşturmuştur. Öğretme eyleminin taksonomisi olarak adlandırılan bu taksonomi, mantıksal olarak düzenlenmiş farklı davranış kategorilerinin tanımlanması ve sınıflandırılmasından oluşmaktadır (Lee, 1973a, s. 32-35). Söz konusu bu taksonomiye göre din öğretiminin altı yapısal içeriği vardır. Lee'nin genelden özele ilerleyen bir sınıflandırma içinde tanımladığı bu içerikler sırasıyla şunlardır: Yaklaşım 
(approach), stil (style), strateji (strategy), metot (method), teknik (technic) ve adim (step) (Lee, 1972c, s. 369 ve 1978b, s. 23).

Yaklaşım, kişinin öğretme eylemine yönelik temel yönelimidir. Sosyal bilim yaklaşımı ve teolojik yaklaşım gibi (Lee, 1971a, s. 33). Stil, öğrenme faaliyetlerinin yönünü belirleyen öğretim modelidir. Bu modelden, metotlar ve teknikler neşet eder. Din öğretiminde yaygın olarak bilinen stiller: Öğretmen merkezli, öğrenci merkezli (Lee, 1983b, s. 36 ve 1992, s. 197). Strateji, öğretme-öğrenme eyleminin belli yöntem ve tekniklerini içeren kapsamlı, sistemli, somut bir iskeledir (Lee, 1971a, s. 34 ve 1992, s. 197). Din öğretiminde yaygın olarak kullanılan stratejiler: Aktarma stratejisi, yapılandırılmış öğrenme stratejisi (Lee, 1977, s. 131). Metot, öğretme-öğrenme eyleminde kullanılan bir dizi pedagojik prosedürdür. Bireysel öğretim, problem çözme din öğretiminde kullanılan başlıca metotlardır. Teknik, belirli bir öğretme-öğrenme durumunda bir pedagojik olayın yapılandırıldığı somut ve spesifik yoldur. Adım, öğretim uygulamasında ortaya konulan son derece spesifik davranış birimi veya davranış dizisidir. Adım, pedagojik eylemin en doğrudan gözlemlenebilir özelliğidir ve öğrenci davranışının bağlı olduğu, önceden ayrıntıları ile belirlenmiş öncül öğretmen davranış1 olarak hizmet eder (Lee, 1992, s. 197-199).

Lee'nin öğretme eyleminin taksonomisi, din eğitimcilerinin eğitsel etkinliklerinde iç pedagojik uyumu yakalamaları ve böylece din eğitiminde verimi arttırmaları açısından önemlidir.

Din öğretiminin özsel içeriği. Özsel içeriğin muhtelif öğrenme türlerini ortaya çıkaran birbirinden farklı, ancak birbiri ile etkileşim içinde olan alt içeriklerden meydana geldiğini belirten Lee, deneysel araştırma verilerine dayanarak; ürün içeriği (product content), süreç içeriği (process content), bilişsel içerik (cognitive content), duyuşsal içerik (affective content), sözlü içerik (verbal content), sözsüz içerik (nonverbal content), bilinç dışı-bilinçli içerik (unconsciousconscious content) ve yaşam tarzı içeriği (lifestyle content) olmak üzere dokuz içerik tanımlar (Lee, 1985b, s. 13-17 ve 1992, s. 173). Din öğretiminin özsel içeriği olan din, bu alt içeriklerin etkileşimine bağlı olarak değişik biçimlere bürünür (Lee, 1982, s. 116 ve 1988a, s. 154).

Herhangi bir aktivite veya çalışmanın sonucu olarak kabul edilen, dolayısıyla somut bir şekilde gözlemlenebilen (Baatuma, 1986, s. 174) ve genellikle statik olan içeriği Lee, ürün içeriği olarak tanımlar (Lee, 1992, s. 173). Ürün içeriği her ne kadar daha çok bilişsel bir etkinliğin kazanımı olarak görülse de duyuşsal ve yaşam tarzı ekinlikleri sonucunda ortaya çıkan pek çok ürün içeriği de vardır 
(Lee, 1985b, s. 40-41). Teolojik yaklaşım savunucuları din öğretiminin tek ürün içeriğinin teoloji olduğunu iddia ederler. Teolojinin, bilişsel ürün içeriği olarak özsel içerikte önemli bir yeri olduğunu kabul etmekle birlikte Lee, özsel içerik için tek bir ürün içeriğinden söz etmenin mümkün olmadığını, teolojik yaklaş1mın bu iddiasının emperyalistçe olduğunu belirtir (Lee, 1985b, s. 40).

Süreç içeriği, ürün içeriğinin aksine dinamik ve soyuttur (Burgess, 1996, s. 196). Lee, din öğretimi de dâhil varoluşsal her eylemin, ürün ve süreç içeriğinin bileşiminden oluştuğunu, dolayısıyla bu iki içeriği birbirinden tamamen ayırmanın mümkün olmadığını belirtir. Çünkü ürün ve süreç içeriği arasında varoluşsal bir ayrımdan ziyade kavramsal bir ayrım söz konusudur. (Lee, 1985b, s. 35-36). Ayrıca Lee, sürecin basitçe içeriği aktarmanın bir yolu olmadığını, özü itibariyle bizatihi gerçek bir içerik olduğunu (Lee, 1978b, s. 22), bu yüzden ürün içeriğinden daha önemli olduğunu vurgular (Lee, 1992, s. 173). Çünkü Lee'nin yaklaş1mında din, yaşanan bir deneyim olarak bizatihi bir sürece işaret etmektedir.

Bilişsel içerik, entelektüel içeriktir. Ancak bu içerik, hem entelektüelleştirme sürecinin sonucunda ortaya çıkan ürün içeriğini hem de entelektüelleştirmenin süreç içeriğini kapsar (Lee, 1992, s. 175 ve 1985b, s. 129). Çünkü biliş, hem bir düşünme ürünü hem de bir süreçtir. Süreç olarak biliş, düşünme biçimidir. Lee’ye göre düşünme biçimimiz ne düşündüğümüzden daha önemlidir. Çünkü düşünme biçimimiz, düşündüğümüz şeyi güçlü biçimde etkiler (Lee, 1987a, s. 51). Bilişsel içerik, bilgi (knowledge), anlama (understanding) ve hikmet (wisdom) olmak üzere üç kademeden oluşmaktadır. Bilgi, gerçeğin basit bir şekilde anlaşılması, belirli bir gerçekliğin temelinde yatan gerçeklerin fark edilmesidir. Anlama, belirli bir gerçekliğin altında yatan temel ilkelerin ve nedenlerin kavranmasıdır. Hikmet, belirli bir gerçekliğin nihai sebebi olarak tanımlanmaktadır. Lee'ye göre hikmet, bilişsel kazanımın zirvesidir (Lee, 1985b, s. 134,159 ve 1987a, s. 50-51). Dinî alanda hikmet, bir insanın her şeyi Tanrı ile ilişkilendirmesi, tüm sonuçları ve gerçekliği Tanrı'ya bağlaması anlamına gelir (Lee, 1987a, s. 51).

Duyuşsal içerik, duyguları, tutumları ve değerleri, bir başka deyişle his ile karakterize edilen her türlü içeriği ifade eder (Cullen, 2005, s. 179) ve hem his sürecini hem de bu his sürecinden elde edilen ürün içeriğini kapsar (Lee, 1985b, s. 196). Din öğretiminin hem bilişsel hem de duyuşsal içeriği içermesi gerektiğini belirtmekle birlikte Lee, yaklaşımında özellikle duyuşsal içeriğe odaklanmaktadır. Çünkü deneysel araştırmalar duyuş ve dinî davranış arasında derin bir bağ olduğunu ortaya koymaktadır (Baatuma, 1986, s. 176). 
Sözlü içerik, dini öğretirken kullanılan birtakım kelimeler dizisidir. Doğası itibariyle duyuşsal olmaktan ziyade bilişsel olan bu içerik, yalnızca diğer içerikleri iletmek için kullanılan bir araç değil, bizatihi bir içeriktir. Çünkü öğrencinin ve eğitimcinin kullandığı sözcüklerin kendileri mesajdır veya mesajın sözel bir parçasıdır. Dolayısıyla din öğretmeni sözlü içeriği bizatihi otantik bir özsel içerik olarak kabul etmelidir (Lee, 1985b, s. 276-277). Teolojik yaklaşım savunucuları sözlü içeriğin din öğretiminin bütününü oluşturduğunu iddia etmektedirler. Çünkü onlar için din öğretiminin özü teolojik içeriği saf bir şekilde öğrenciye aktarmaktır (Lee, 1970b, s. 81 ve 1985b, s. 292).

Sözsüz içerik, din eğitimcisinin dini öğretirken kullandığı fiziksel ifadeler, jest ve mimikler, hareketler veya sesler kümesi, bir başka deyişle kelime kullanılmayan tüm iletişim biçimleridir. Lee’ye göre sözsüz içerik kendi başına bir içerik olmakla birlikte diğer içerik türlerinin de taşıyıcısı olduğundan din öğretiminde son derece önemlidir (Lee, 1985b, s. 276-277).

Bilinçdışı içerik, kişinin farkındalık seviyesinin altına düşen içerik olarak tanımlanmaktadır. Bu içerik, kişinin farkındalık seviyesinin dışında olduğu için nasıl çalıştığını, hatta "orada" bir şey olup olmadığını bilmek mümkün değildir (Lee, 1985b, s. 475-476). Serbest çağrışım egzersizlerinde, hayallerde ortaya ç1kan bilinç dışı içerik din öğretiminin de önemli içeriklerinden birini oluşturmaktadır (Lee, 1992, s. 175). Çünkü öğrencinin özellikle duyuşsal düzeyde öğrendiklerinin rengi ve dokusu üzerinde güçlü bir etkiye sahiptir (Burgess, 1996, s. 198).

Lee'nin yaklaşımında sürekli olarak vurguladığı ilkelerden biri holizm (holism)'dir. Bilinçli insan faaliyetleri ve bilinç dışı insan faaliyetleri arasındaki dinamik ilişki açısından holizm, bilinç ve bilinç dışı süreçler arasında bir sınır çizmenin hem çok zor hem de yanlış olduğu anlamına gelmektedir. Sürekli olarak insanın homo integer olduğuna ve kişiliğin bir bütün olarak işlev gördüğüne vurgu yapan Lee, hem bilimsel olarak hem de holistik olarak bilinç ve bilinç d1şını birbirinden ayırmanın doğru olmadığını belirtir (Lee, 1985b, s. 484). Çünkü din öğretim eyleminde öğretmen bir bütün olan öğrenci ile yalnızca bilinç alanında değil bilinç dışı alanda da etkileşime girer (Baatuma, 1986, s. 180). $\mathrm{Bu}$ yüzden Lee, etkili bir din öğretimi için öğretmenin hem kendi bilinç dış1 davranışlarının hem de öğrencinin bilinç dışı davranışlarının farkında olması ve kendi bilinç dışı süreçlerini öğrencinin bilinç dışı süreçlerine uydurması gerektiğini belirtir (Lee, 1985b, s. 515).

Lee, din öğretiminin özsel içeriğini oluşturan dokuz içerik içerisinde en önemli içeriğin yaşam tarzı içeriği olduğunu belirtir. Çünkü yaşam tarzı hem 
kendi başına bir içeriktir hem de diğer tüm içeriklerin işlevsel koordinasyonunu gerçekleştirmektedir. Bilişsel, duyuşsal ve psikomotor davranışların hâlihazırdaki dinamik entegrasyonundan oluşan yaşam tarzının temel karakteristik özelliği bütünleştirici oluşudur. Buna göre yaşam tarzı içeriği, en genelinden en özeline bir kimsenin beşeri fonksiyon repertuvarını içermesi bakımından bütünsel, sayısız insan aktivitesini ve davranışını, bir dereceye kadar uyumlu bir kişisel işleyiş modeli haline getirmesi bakımından bütünleştiricidir (Lee, 1985b, s. 608-612, 629). Bütünsellik ile aslında Lee, bilişsel, duyuşsal ve yaşam tarzı içeriklerinin birbirine entegre olmasını kastetmektedir. Dolayısıyla etkili bir din öğretimi, öğrencinin psikomotor, bilişsel, duyuşsal ve yaşam tarzı davranışlarının tamamına odaklanmalıdır.

Din öğretim içeriği ve din öğretim metodu arasında bir düalizm olmadığının altını çizmekle birlikte Lee, bir eğitimcinin öğretme şeklinin, öğrenen üzerinde, eğitimcinin öğrettiği özsel içerikten çok daha fazla etkiye sahip olduğunu iddia eder. Buna göre yapısal içerik genellikle eğitim dinamiğindeki özsel içerikten daha güçlü bir içeriktir; çünkü özsel içeriği değiştirir ve eğitim dinamiğinin temel bileşenini oluşturur (Lee, 1992, s. 177).

\section{Teolojik Yaklaşımın Metodolojisi ve Temel Argümanları}

Sosyal bilim yaklaşımını teolojik yaklaşım eleştirisi üzerine inşa eden Lee zaviyesinden teolojik yaklaşımı reddederken, teolojinin ne olduğu, hangi özelliklerinin veya yönteminin din öğretim faaliyeti için uygun olmadığını ortaya koymak önemlidir. Çünkü bu hususlar, din öğretiminin sosyal bilimin mi yoksa teolojinin mi bir disiplini olduğu noktasında önemli içerikler ortaya koyacaktır.

Teolojinin mahiyetine ilişkin Hristiyan dünyasında şaşırtıcı düzeyde farklı teolojik görüş mevcuttur. Bu yüzden Lee, teoloji yerine teolojiler ifadesini kullanmanın abartı olmayacağını ifade eder (Lee, 1971a, s. 101). İncil'de hiçbir yerde kullanılmayan teoloji kavram1, St. Thomas tarafindan Hristiyan iman bilimi olarak literatüre kazandırılmıştır (Van Ackeren, 1967, s. 39). Etimolojik olarak Yunanca theos ve logos kelimelerinden meydana gelen teoloji (theology), Tanrı'ya ilişkin düşünme ve konuşmaların organizasyonu (Jenkins, 1984, s. 343), akademik bir disiplin olarak Tanr bilimi anlamına gelmektedir (Little, 1990, s. 649). Hristiyan teologlara göre teoloji, iman aracıllğ̣ ile kilisenin vaz etmek zorunda olduğu ve Hristiyanların da inanmak zorunda olduğu hususları entelektüel açıdan açılı̆ğa kavuşturmak için çaba sarf eder (Brunner, 1964, s. 178-181). 
Lee'ye göre teoloji, Tanrı'yı ve O'nun fiillerini sistematik bir şekilde keşfetmek ve açıklamak (Lee, 2000, s. 256) için hem aklı hem de ilahî vahyi kullanan bilişsel bir araştırma biçimi (Lee, 1982, s.108), Tanrı ve Tanrı'nın evrenle ilişkisi konusu ile ilgilenen bir inceleme alanıdır. Bu dünyada tecellileriyle bilinmek isteyen Tanrı'yı kavramak ve sarih bir şekilde açılamak teolojik incelemelerin görevidir (Lee, 1971a, s. 103-104).

\section{Teolojik bilimin metodolojisi}

Lee'nin sosyal bilim yaklaşımını teolojik yaklaşıma tercih etmesinin temel nedenlerinden biri her iki bilim arasındaki metodoloji farkıdır. Çünkü teolojik bilim, öncelikli ilkeleri ve araştırma metotları açısından diğer bilimlerden esaslı bir şekilde ayrılmaktadır. Özellikle doğrulama metodu ile teologların profan bilimler olarak adlandırdığ 1 bilimlerden esaslı bir şekilde ayrılan (Hick, 1960, s. 12-31; Ommen, 1979, s. 357-384; Allen, 2017, s. 417-433) teolojiyi kendine özgü yapan temel özellik, araştırdığı tüm verilerin başlangıç ve bitiş noktası itibariyle Tanrı ile ilişkili olması veya referansının Tanrı olmasıdır (Lee, 1971a, s. 112-113).

Teolojide doğrulama metodu olarak; Kutsal Kitap (scripture), öğretme yetkisini elinde bulunduran kutsal kurum majisteryum (magisterium), gelenek (tradition), iman (faith) ve doğal mantık (natural logic) kullanılır (Lee, 1971a, s. 122). Lee, bu beş temel doğrulama metodunu iki başlık altında toplar. Çünkü bunların ilk dördü doğaüstü; sonuncusu ise doğaldır. Dolayısıyla teolojik bilimde kullanılan birincil doğrulama metodu doğaüstüdür (Knudsen, 1966, s. 158-159). Lee'nin tespitlerine göre doğaüstü olmayan doğal mantık da daima doğaüstü doğrulayıcılar ile bağdaşacak şekilde kullanılmaktadır. Aksi durumda doğal mantık metodolojik açıdan kusurlu olarak görülmektedir (Lee, 1971a, s. 126).

Teoloji, kutsal kitaplara ve kilise dogmalarına dayandığı için doğrulama yöntemleri, kutsal kitap, gelenek, magisterium veya iman aracıllğıyla konuşan Tanrının otoritesinden neşet etmektedir, dolayısıyla deneysel değil spekülatiftir (Lee, 1971a, s. 126-127). Buna karş1lık sosyal bilim, olayların ve ilişkilerin kontrollü gözleminden ve deneysel analizinden neşet etmiştir. Örneğin Hristiyanlığın en temel ilkesi, kişinin komşusunu sevmesidir. Buna göre öğretmen öğrencisinin bu kazanımı edinmesini nasıl sağlayacak veya öğrencisinin söz konusu kazanımı elde edip etmediğini nasıl doğrulayacak? Bu konuda teolojik düşünme mi, Kutsal kitap mı yoksa gelenek mi öğretmene yardımcı olacak? Lee bu konuda teolojik bilimin benimsediği doğrulama yöntemlerinden hiçbiri- 
nin öğretmene yardımcı olamayacağını; ancak ampirik deneylerin ve kontrollü gözlemin doğrulama konusunda öğretmene yol gösterebileceğini belirtir (Merry, 2000, s. 91). Çünkü sosyal bilimlerde önermelerin doğrulanmas1, farklllıklar yöntemi, uyuşma yöntemi, birleşik uyuşma ve farklllık yöntemi, kalıntılar yöntemi, birlikte değişme yöntemi gibi genel doğrulama yöntemlerinden birine göre olayların ve ilişkilerin kontrollü gözlemine ve deneysel testine dayanır (Lee, 1971a, s. 128, 159,189).

Lee'nin sosyal bilimsel din öğretimi yaklaşımının kalbi ampirik gözlemdir. Kişisel ve mistik unsurlar içeren teolojik bilim ise metodolojik açıdan spekülatif olduğundan deneysel bilgiyi imkânsız kılmaktadır. Bu yüzden teolojik yaklaşım savunucularının araştırma sonuçları doğrulama açısından ciddi problemler içerebilmektedir.

\section{Teolojik bir disiplin olarak din eğitimi}

1970'li yılların başlarına kadar, hem Katolik hem Protestan din eğitiminde makro teorik yaklaşım olarak teoloji esas alınmıştır (Baatuma, 1986, s. 113114; Newell, 2004, s. 20). Teolojik makro teori, din eğitimini, pratik teolojinin bir dalı olarak kavramsallaştırır (Thompson, 1978, s. 614-615) ve teolojinin din eğitiminin tüm boyutlarını açıklama, öngörme ve doğrulama imkânına; din eğitiminin gerçekleşebildiği veya gerçekleşme imkânı bulamadığı koşulları bilme ve açıklama; başarılı bir din eğitim müfredatını tasarlama ve etkili öğretme teknikleri icat etme, deneme; kimin etkili bir din öğretmeni olup olmadığını belirleme gücüne sahip olduğunu ileri sürer (Lee, 1982, s. 122 ve 1996, s. 45). $\mathrm{Bu}$ iddianın temel sebebi, teolojinin uzun yıllar bilimlerin özellikle de dinî bilimlerin kraliçesi olarak görülmesidir (Seymour, 2004, s. 282).

Teolojinin din eğitiminin temelini oluşturan Tanrı-insan ilişkisinin incelenmesi ve açıklanması ile ilgili olduğunu belirten teorisyenlere göre teoloji, din eğitim teorisinin kalbidir (Knox, 1976, s. 6). Bu yaklaşımın önde gelen savunucuları D. Campbell Wyckoff, Berard Marthaler, Johannes Hofinger, Randolph Crump Miller ve John Westerhoff III'dır (Lee, 1990b, s. 599). Teoloji ve eğitim arasındaki ilişkide Westerhoff III, teolojinin, eğitimin ne olduğunu ve nasıl olduğunu belirleyen bir referans noktası, bir norm olduğunu belirtir. Ona göre teolojik varsayımlar din eğitiminin (catechesis) hem teorisini hem de pratiğini anlamak için bir filtredir (Westerhoff III, 1978, s. 284-285). Lee'nin karşı kutbunu temsil eden teolojik yaklaşımın meşhur savunucularından Miller'a göre teoloji, Hristiyan eğitiminin anahtarıdır ve din eğitim teorisinin her yönü için 
kural koyucudur, normatiftir (Miller, 1950). Buna göre teoloji, eğitim felsefesinin, kullanılacak tekniklerin, ulaşlacak hedeflerin belirlenmesinde belirleyici faktördür (Thompson, 1978, s. 612). Dolayısıyla din eğitiminin doğası ve kapsayıcı makro teorisi temel olarak teolojik olmalıdır. Çünkü din eğitiminin amaçları, din öğretimi işlemleri ve din öğretiminin makro teorisi gizli veya açık teolojik varsayımlar içermektedir (Miller, 1980, s. 2, 153-154). Lee’ye göre Miller'ın bu iddiası gerçeklikler arasındaki birincil varlıksal ve işlevsel ayrımları yok saymaktadır. Çünkü Tanrı'nın yarattığı ve nüfuz ettiği bir dünyada sanat, edebiyat, hatta çiftçilik vb. her insan faaliyeti belirli teolojik varsayımlar içermektedir. Lee'ye göre din öğretiminin temelde teolojik varsayımlara sahip olduğunu ve bu yüzden teolojik olduğunu iddia etmek, sanatın, edebiyatın hatta çiftçiliğin birtakım teolojik varsayımlara sahip olduğu için temelde teolojik olduğunu iddia etmek kadar anlamsızdır (Lee, 1996, s. 46).

Din öğretiminin kendine özgü, eşsiz bir varlığa sahip olduğunu belirten (Lee, 1973b, s. 282) Lee'ye göre din öğretimi pratik teolojinin bir kolu değildir, dolayısıyla teolojik bir disiplin değildir (Lee, 1971a, s. 108). Çünkü pratik teoloji, Tanrı'nın vahyi ve insanoğlunun bir Hristiyan olarak yaşamının sonuna kadar bu vahye verdiği tepki arasındaki ilişkiyi inceler (Lee, 1971a, s. 107, 241). Kiliseye özgü pratik teoloji ile pratiğin kendisi arasında çok büyük varlıksal bir farklılık vardır. Teoloji, kilise tarafından ifa edilen pratikler üzerine bilişsel bir düşünmedir. Dolayısıyla teoloji, kilise tarafından icra edilen pratikle aynı şey değildir. Bir başka deyişle pratik teoloji, kilise pratiğinin teolojisidir, pratik ile pratiğin teolojisi ise aynı şey değildir. (Lee, 1996, s. 47 ve 2000, s. 263-265). Lee'ye göre eğer pratik üzerine düşünme veya pratiğin teolojisi, pratiğin kendisi ile aynı olsaydı, o zaman tüm gerçeklik esas itibariyle teolojik olurdu ki bu da bir tür indirgemecilik veya teolojik emperyalizm olurdu (Lee, 1995, s. 542-543 ve 1990b, s. 600). Ayrıca Tanrı'nın yarattıkları, tıpkı felsefi bir boyuta sahip oldukları gibi, teolojik bir boyuta da sahiptir. Fakat Tanrı'nın yaratıklarının her birinin mahiyeti ve çalışması, bu boyutların herhangi birine indirgenerek izah edilemez (Lee, 1982, s. 126 ve 1996, s. 48).

Kognitif bir bilim olan teoloji, genellikle dini kendi entelektüel perspektifinden ikincil düzeyde ele alıp inceler (Lee, 1991, s. 217). Bu yüzden Lee, bir yaşam biçimi olarak kabul ettiği din ile bir düşünme biçimi olarak kabul ettiği teoloji arasında kesin bir ayrım öngörür. Ona göre öğretme-öğrenme süreçleri ile alakadar olan din öğretimi, öğrencinin daha zengin bir dinî yaşam sürdürebilmesi için öğrenme durumunun yapılandırılması ile ilgilenir (Lee ve Hiltz, 
1968, s. 557-558). Dolayısıyla spekülatif ve bilişsel bir bilim olan teoloji, din öğretim süreci ile uyuşmaz. Çünkü teoloji, doğrudan dini veya dinî davranış1 ortaya çıkaramaz. Bir bütün olarak din, hayat boyu süren bir ilişki, yaşanan deneysel bir gerçekliktir. Bilişsel içerik esasen yaşam tarzı içeriğinden farklı olduğundan teolojik içerik Hristiyan yaşam tarzını ortaya çıkaramaz (Lee, 1985a, s. 21). Nitekim bilimsel araştırmalar ortaya koymuştur ki biliş, hayat tarzı gibi bilişsel olmayan sonuçlar ortaya çıkaramaz (Lee, 1992, s. 190 ve 2000, s. 256257). Dolayısıyla, kişisel dindarlık için çabalayan din eğitimcinin sadece teolojik düşünceleri dikkate alması uygun değildir (Lee, 1973b, s. 278, 282).

Lee, her ne kadar sürekli olarak teolojik bilim ile sosyal bilim arasındaki farka vurgu yapıp din öğretimini teoloji biliminin sınırlarının dışında tutsa da esasında teoloji ile sosyal bilim arasında, özsel içerik olarak teolojinin kendine uygun rolü üstlendiği işbirliğine dayalı bir ilişki biçimi öngörmektedir. Dolayısıyla iddia edildiği gibi Lee'nin yaklaşımı teolojiz bir din öğretimini savunmamaktadır (McBrien, 1976, s. 174-175; Darcy-Berube, 1978, s. 119-120; Newell, 2004). Lee'nin yaklaşımında ne teoloji din öğretimi için bir norm, ne de din öğretimi teolojik içeriğin bir taşıyıcısı veya hizmetçisi olarak hizmet görmektedir. Bu bağlamda Lee zaviyesinden din öğretimi-teoloji ilişkisini daha detaylı bir şekilde ortaya koymak, sosyal bilimsel din öğretim yaklaşımını farklı boyutlarıyla daha iyi anlamak açısında faydalı olacaktır.

\section{Sosyal Bilimsel Din Öğretiminin Teoloji İle İlişkisi}

Sosyal bilim olarak din öğretiminin ayırt edici özelliklerinden biri değer-yarglsızlıktır (Lee, 1971a, s. 142, 207). Dinî fenomenleri açıklamayı, öngörmeyi ve doğrulamayı hedefleyen hiçbir makro teorinin, politik ve dinî açıdan tekelci olmaması gerektiği ilkesini benimseyen (Lee, 1973b, s. 281-282) Lee'nin sosyal bilim yaklaşımında değer-yargısızlık, din öğretiminin teolojik yargılardan bağımsız olması anlamına gelmektedir (Lee, 1971a, 207). Değer-yargısız din öğretimi vurgusu ile Lee, din öğretiminin teoloji ile hiçbir ilişkisi olmadığını veya teolojiyi tamamen dışladığını iddia etmediğinin altını çizer. Çünkü Lee'ye yöneltilen eleştirilerin başında teolojisiz bir din öğretimi öngördüğü iddiası gelmektedir (Newell, 2006, s. 7). Yaklaşımında teolojinin rolünü yadsımayan Lee, aslında, din öğretiminin Pratik teolojinin bir kolu olarak kavramsallaştırılması anlayışına itiraz etmektedir. Çünkü Lee din öğretiminin ontolojik olarak teolojiden farklı olduğunu ileri sürmektedir.

Teolojinin din öğretiminde normatif bir role sahip olduğunu, dolayısıyla din öğretiminin her yönü ile tamamen teoloji tarafından belirlendiğini ileri süren 
teolojik yaklaşım savunucularının (Lee, 1971a, s. 245 ve 1973a, s. 21) söz konusu iddialarına karşılık Lee, teolojinin din öğretiminin özsel içeriğinde kilit bir role sahip olduğunu ancak hiçbir şekilde din öğretiminin belirleyici normu olamayacağını belirtir (Lee, 1971a, s. 246). Ona göre teoloji, din öğretiminde dâhili ve harici olmak üzere iki role sahiptir (Lee, 2000, s. 257). Teoloji, din öğretiminin özsel içeriğinin yani dinin bir boyutu olduğunda dâhili rolünü yerine getirmiş olur. Böylece teoloji, din öğretim faaliyetinin bir parçası haline gelir ve din öğretim olayında kendine uygun rolü üstlenir (Lee, 2000, s. 257). Ancak teolojinin din öğretim işinde icra ettiği rol din öğretimi tarafindan belirlenir. Bir başka deyişle teolojinin dâhili rolünü tam anlamıyla yerine getirebilmesi için teoloji terimlerine değil din öğretiminin özsel içeriğinin terimlerine dayanması gerekir (Savage, 1990, s. 27). Ayrıca din öğretim sürecinde yer alan diğer değişkenler din öğretim faaliyetinde nasıl bir role sahipse teoloji de benzer bir role sahiptir. Çünkü teoloji, din öğretim ameliyesinde yer alan özsel içerik, öğrenci, öğretmen, öğrenme ortamı vb. tüm değişkenler ile de sürekli etkileşim halindedir. Teolojinin din öğretimi ile ilişkisi söz konusu bu dinamik etkileşim içinde sürüp gider (Lee, 1978a, s. 54-55).

Lee'ye göre teoloji, din öğretiminin teolojik anlamı üzerinde düşündügünde harici rolünü yerine getirmiş olur. Bir başka deyişle teoloji, din öğretiminin, din öğretimi açısından anlamı üzerinde değil de teoloji açısından anlamı üzerine düşündügünde harici rolünü yerine getirmiş olur. Buna göre din öğretimi, din öğretim işini daha da geliştirmek maksadıyla teolojik düşünmeyi kullanabilir. Fakat bu, teolojik düşünmenin, din öğretiminin pedagojik dinamiğiyle aynı veya ona eşdeğer olduğu anlamına gelmez. Din öğretimi, bir din öğretimi teolojisinden yalnızca din öğretimi işini herhangi bir şekilde daha ileriye taşımak ve geliştirmek açısından yararlanabilir (Lee, 1982, s. 155-156).

Özetle; teolojinin din öğretim işindeki asıl fonksiyonu, din öğretimi adı verilen teolojik olmayan gerçekliğin teolojik anlamı üzerinde düşünmektir. Din öğretimi kavramlarını, olgularını ve yasalarını açıklamaya, öngörmeye ve doğrulamaya çalışmak değildir. Buna göre teoloji, din öğretiminin yapısal içeriği açısından hiçbir role sahip değildir (Lee, 1978a, s. 50-54). Ancak Lee’ye göre bu durum sosyal bilimsel din öğretimi yaklaşımının teolojik içeriğin değerini düşürdüğü anlamına gelmez. Aksine sosyal bilimsel din öğretimi, gerekli koşulları oluşturarak gerçek teolojik öğrenmelere olanak sağlar (Lee, 1969, s. 24). Bu yüzden din öğretimi, uygulamalı teoloji olarak da adlandırılmaktadır (Merry, 2000, s. 85). 
Lee, teolojik yargilara tabi olmamakla sosyal bilimsel din öğretiminin, profesyonel işbirliğini teşvik etmek suretiyle teolojinin din eğitimcilerini birbirinden ayırma eğiliminde olduğu hususlarda işbirliğini artırabileceğini ve dinî çoğulculuğu kolaylaştırabileceğini belirtir (Lee, 1988b, s. 109-124) Böylece farkl1 dinî eğilimlere sahip eğitimciler inanç sınırları boyunca birbirlerinin çalışmalarını kullanabilir veya birbirlerinden yararlanabilirler (Lee, 1971a, s. 4).

\section{Sonuç}

Bilimsel bir çalışma alanı olarak din eğitiminin ilahiyat bilimlerinin mi yoksa sosyal bilimlerin mi bir disiplini olduğu problemi, din eğitim bilimcilerinin araştırma alanları ile ilgili teori ve ilkelerini ortaya koyarken hangi bilimleri esas alacaklarını bilmeleri açısından son derece önemlidir. Çünkü söz konusu teori ve ilkeler pratik uygulamalara kaynaklık etmektedir. Dolayısıyla din eğitiminin hangi disiplinler kategorisinde yer alması gerektiğine karar vermek hem teorik hem de pratik açıdan önem arzetmektedir. Din eğitimi için en uygun makro teoriyi tespit etmenin yolu, din eğitim sürecinin ne olduğu ve din eğitiminin tam olarak ne iş yaptığı ile ilgili soruları açıklığa kavuşturmaktan geçer. Lee'nin yaklaşımına göre din eğitimi, dinî öğrenmeyi kolaylaştırır. O halde din eğitiminin mahiyeti, öğrenme kazanımlarını ortaya çıkarıp çıkarmadığına bakılarak izah edilebilir. Buna göre din eğitimi için uygun bir makro teori, öğretme-öğrenme hadisesinin gerçekte nasıl ortaya çıktığını, din eğitiminde mevcut temel değişkenlerin (öğrenci, öğretmen, öğrenme konusu ve öğrenme ortamı) hedeflenen öğrenme kazanımları kolaylaştırılacak şekilde nasıl birbiriyle etkileşim içine girdiklerini kapsamlı ve sistematik bir şekilde açıklayabilme, öngörebilme ve doğrulayabilme gücüne sahip olmalıdır. $\mathrm{Bu}$, din öğretimi için uygun herhangi bir makro teori araştırmasında önemli bir ölçüttür. Bu ölçüte göre din eğitimi için en uygun makro teori teoloji değil, sosyal bilimdir. Çünkü dinî öğrenmeyi Kutsal Ruh'a havale eden ve bu suretle diğer öğrenme türlerinden ay1ran teolojik makro teori, öğrenme yasalarını ihmal etmekte, din eğitiminin çok boyutluluğu yerine sadece aktarılan içeriğe odaklanmakta, dolayısıyla öğretim sürecinin diğer önemli değişkenlerini hem ihmal etmekte hem de bu değişkenler arasındaki ilişkiyi yani öğrenmenin nasıl gerçekleştiğini izah edememektedir.

Teoloji, öncelikli ilkeleri ve araştırma metotları, özellikle doğrulama metotu açısından teologların profan bilimler olarak niteledikleri bilimlerden esaslı bir şekilde ayrılır. Çünkü diğer bilimler Tanrı'nın kelamını, imanı veya majisteryumu öncelikli delil olarak kullanmaz. Dolayısıyla teolojik bilim metot açısından 
doğaüstü ve spekülatiftir; kişisel ve mistik unsurlar ihtiva etmekte dolayısıyla ampirik bilgiye imkan tanımamaktadır. Bu yüzden teoloji, deneysel bir araştırma alanı olan din eğitimi için uygun makro teori olamaz. Çünkü din eğitimin özü öğretmedir. Deneysel bir faaliyet olan öğretme ise bilişsel ve spekülatif bir bilim olan teolojinin değil, sosyal bilimin işidir. Bu yüzden Lee'nin din öğretiminde uygulanan temel kavram ve yasalar, sosyal bilimlerin ve özellikle de öğretme-öğrenme süreciyle ilgili kavram ve yasalarıdır.

Din ve öğretimin mahiyetini ele alış şekli, din öğretiminin odak noktaları, içeriği, öğretim sürecinde öğrenme ortamını yapılandırmadaki rolü dolayısıyla öğretmene yaptığı vurgu ve hayatla iç içe bir din anlayışı ile hem teorik hem de pratik açıdan din öğretimine önemli katkılar sunan Lee'nin yaklaşımında öğretme eylemi kendi içinde herhangi bir dinî değer veya inanç kümesini barındırmamakta yani değer-yargısızdır. Dolayısıyla farklı teolojiler için bir temel oluşturan bu yaklaşım, çeşitli inanç pozisyonlarının savunucularına kendi inançlarını öğretme imkânı sunması açısından da önemli bulunmaktadır.

\section{Kaynakça}

Allen, P. L. (2017). Is there verification in theology?. Open Theology, 3(1), 417433.

Aydın, M. Ş. (2017). Din eğitimi bilimi. Kimlik Yayınevi.

Baatuma, W. S. (1986). An integrative approach to teaching-learning processes derived from the theories of Randolph Crump Miller and James Michael Lee (Yayımlanmamış doktora tezi). The Faculty of The Southern Baptist Theological Seminary.

Bilgin, B. (2001). Eğitim bilimi ve din ĕgitimi. Gün Yayıncılık.

Burgess, H. W. (1974). James Michael Lee's social-science approach to religious instruction. Notre Dame Journal of Education, 3, 293-212.

Burgess, H. W. (1975). An invitation to religious education. Religious Education Press.

Burgess, H. W. (1996). Models of religious education: Theory and practice in historical and contemporary perspective. Victor Books.

Brunner, E. (1964). Truth as encounter. Westminster Press.

Coe, G. A. (1917). A social theory of religious education. C. Scribner's sons.

Coughlin, K. J. (1981). Religious education in everday life (Yayımlanmamış doktora tezi). The Faculty of the Graduate Theological Union. 
Cullen, W. (2005). James Michael Lee: A social science approach to religious instruction. Lutheran Educational Journal, 140(3), 160-185.

Darcy-Berube, F. (1978). The challenge ahead of us. Padraic O'Hare (Ed.), Foundations of religious education içinde (ss. 111-131). Paulist Press.

Glock, C. Y. (1962). On the study of religious commitment. Religious Education, 57(4), 98-110.

Goldbrunner, J. (1961). Catechetical method as handmaid of kerygma. Johannes Hofinger (Ed.), Teaching all nations: A symposium on modern catechetics içinde (ss. 108- 121). Herder and Herder.

Goldman, R. (1964). Religious thinking from childhood to adolescence. Routledge and Kegan Paul.

Hick, J. (1960). Theology and verification. Theology Today, 17(1), 12-31.

Hobson, P. \& Louise, W. (2002). Modal shifts and challenges for religious education in catholic schools since Vatican II. CEJ, 6, 55-71.

Johannes, H. (1961). The art of teaching Christian doctrine: The good news and its proclamation. University of Notre Dame Press.

Jenkins, D. E. (1984). Theology. John M. Sutcliffe (Ed.), A Dictionary of Religious Education içinde (ss. 343). SCM Press.

Knox, I. (1976). Above or within? The supernatural in religious education. Religious Education Press.

Knudsen, R. D. (1966). Rudolf Bultmann. Philip Edgcumbe Hughes (Ed.), Creative minds in contemporary theology içinde (ss. 131-159). Eerdmans.

Küken, G. (1996). Doğu-batı felsefesi etkileşiminde İbn Rüşd ve St. Thomas Aquinas felsefelerinin karşılaştırılması. Alfa Yayınevi.

Lee, J. M. (1963). Principles and methods of secondary education. McGraw-Hill.

Lee, J. M. \& John T. H. (1968). Diocesan religion programs: A national survey. The Catholic Educational Review, 66, 553-565.

Lee, J. M. (1969). The third strategy: Social science catechetics. Today's Catholic Teacher, (November), 21-28.

Lee, J. M. (1970a). Behavioral objectives in religious instruction. The Living light, 7(4), 12-19.

Lee, J. M. (1970b). The teaching of religion. James Michael Lee \& Patrick C. Rooney (Ed.), Toward a future for religious education içinde (ss. 55-92). Pflaum Press.

Lee, J. M. (1971a). The shape of religious instruction: A social science approach. Religious Education Press. 
Lee, J. M. (1971b). Toward dialogue in religious instruction. The Living Light, 8, 109-121.

Lee, J. M. (1972a). Religious Education's Future. National Catholic Reporter, (October), 10.

Lee, J. M. (1972b). Prediction in religious instruction. The Living Light, 9, (Summer), 43-54.

Lee, J. M. (1972c ). Hope in instructional practice. Religious Education. 67(5), 368-374.

Lee, J. M. (1973a). The flow of religious instruction: A social science approach. Religious Education Press.

Lee, J. M. (1973b). Religious education and the catholic university. Notre Dame Journal of Education, 4(3), 276-283.

Lee, J. M. (1976). Roman Catholic religious education. Marvin J. Taylor (Ed.), Foundations for Christian education in an era of change içinde (ss. 242258). Abingdon.

Lee, J. M. (1977). Toward a new era: A blueprint for positive action. James Michael Lee (Ed.), The religious education we need: Toward the renewal of Christian education içinde (ss. 112-155). Religious Education Press.

Lee, J. M. (1978a). Key issues in the development of a workable foundation for religious instruction. Padraic O'Hare (Ed.), Foundations of religious education içinde (ss. 40-63). Paulist Press.

Lee, J. M. (1978b). Process content in religious instruction. Iris V Cully, Kendig Brubaker Cully \& Randolph Crump Miller (Ed.), Process and relationship: Issues in theology, philosophy, and religious education: A festschrift for Randolph Crump Miller içinde (ss. 22-30). Religious Education Press.

Lee, J. M. (1980). Christian education and moral development. Brenda Munsey (Ed.), Moral development, moral education, and Kohlberg: Basic issues in philosophy, psychology, religion, and education içinde (ss. 326-355). Religious Education Press.

Lee, J. M. (1981). Training religious educators II. Modern Ministry. (December), 26-29.

Lee, J. M. (1982). The authentic source of religious instruction. Norma H. Thompson (Ed.), Religious education and theology içinde (ss. 100-197). Religious Education Press.

Lee, J. M. (1983a). To basically change fundamental theory and practice. Marlene Mayr (Ed.), Modern masters of religious education içinde (ss. 254-323). Religious Education Press.

Lee, J. M. (1983b). Religious education and the Bible: A religious educationist's view. Joseph S. Marino (Ed.), Biblical themes in religious education içinde (ss. 1-61). Religious Education Press. 
Lee, J. M. (Ed.). (1985a). Lifework spirituality and the religious educator. The spirituality of the religious educator içinde (ss. 7-42). Religious Education Press.

Lee, J. M. (1985b). The content of religious instruction: A social science approach. Religious Education Press.

Lee, J. M. (1987a). Forward to the basics. Catechist, (March), 50-56.

Lee, J. M. (1988a). How to teach: foundations, processes, procedures. Donald Ratcliff (Ed.), Handbook of preschool religious education içinde (ss. 152-223). Religious Education Press.

Lee, J. M. (1988b). The blessing of religious pluralism. N. H. Thompson (Ed.), Religious pluralism and religious education içinde (ss. 57-124). Religious Education Press.

Lee, J. M. (1988c). Catechesis sometimes, religious education always: Another roman catholic perspective. Marlene Mayr (Ed.), Does the church really want religious education? An ecumenical inquiry içinde (ss. 32-66). Religious Education Press.

Lee, J. M. (Ed.). (1990a). Facilitating growth in faith through religious instruction. Handbook of faith içinde (ss. 264-302). Religious Education Press.

Lee, J. M. (1990b). Social science. Iris V. Cully \& Kendig Brubaker Cully (Ed.), Harper's encyclopedia of religious education içinde (ss. 598-600). Harper \& Row,

Lee, J. M. (1991). Procedures in the religious education of adolescents. Donald Ratcliff \& James A. Davies (Ed.), Handbook of youth ministry içinde (ss. 214-256). Religious Education Press.

Lee, J. M. (1992). General procedures of teaching religion, Donald Ratcliff (Ed.), Handbook of children's religious education içinde (ss. 164-206). Religious Education Press.

Lee, J. M. (1993a). Religious education volunteers are very special. Donald Ratcliff \& Blake J. Neff (Ed.), The complete guide to religious education volunteers içinde (ss. 30-48). Religious Education Press.

Lee, J. M. (1993b). Compassion in religious instruction. Gary L. Sapp (Ed.), Compassionate ministry içinde (ss. 171-216). Religious Education Press.

Lee, J. M. (1995). Religious instruction and religious experience. Ralph W. Hood (Ed.), Handbook of religious experience içinde (ss. 535-567). Religious Education Press.

Lee, J. M. (1996). Religious education and theology. Jeff Astley (Ed.), Theological perspectives on Christian formation: A reader on theology and Christian education içinde (ss. 45-68). W.B. Eerdmans Publishing Company. 
Lee, J. M. (Ed.). (2000). Vision, prophecy, and forging the future. Forging a better religious education in the third millennium içinde (ss. 243-267). Religious Education Press.

Little, S. P. (1990). Theology and education. Iris V. Cully \& Kendig Brubaker Cully (Ed.), Harper's encyclopedia of religious education içinde (ss. 649-655). Harper \& Row.

Merry, M. (2000). Social-science theory in religious education according to James Michael Lee. St. Vladimir's Theological Quarterly, 44(1), 83-102.

Mcbrien, R. P. (1976). Toward an American catechesis. The Living Light, 13(2), 167-181.

Miller, R. C. (1950). The clue to Christian education. Scribner.

Miller, R. C. (1980). The theory of Christian education practice; how theology affects Christian education. Religious Education Press.

Moran, G. (1966). Catechesis of revelation. Herder and Herder.

Newell, E. J. (2004). James Michael Lee's social science religious instruction, (Yayımlanmamış doktora tezi). Teachers College Columbia University.

Newell, E. J. (2006). James Michael Lee's crusade for empiricism. Christian Education Journal, 3(1), 6-26.

Ommen, T. B. (1979). Verification in theology: A tension in the revisionist method. The Thomist: A Speculative Quarterly Review, 43(3), 357-384.

Parladır, S. (1996). Din eğitimi bilimine giriş.

Pazarlı, O. (1967). Din eğitim ve öğretiminde genel metotlar. İrfan Yayınevi.

Peabody, F. G. (1909). The social conscience and the religious life. Religious education, 4(1), 1-6.

Poochigian, R. L. (1986). A critical analysis of selected roman catholic religious education theorists from the perspective of adult education research and theory, (Yayımlanmamış doktora tezi). The University of Wisconsin-Madison.

Savage, M. D. J. (1990). Christian doctrine in adult religious education: A critical study (Yayımlanmamış yüksek lisanas tezi). Durham University, http://etheses.dur.ac.uk/6227/.

Seymour, J. L. (2004). The clue to Christian religious education: Uniting theology and education, 1950 to the present. Religious Education, 99(3), 272-286.

Tosun, C. (2001). Din eğitimi bilimine giriş. (2. B. ), Pegem A Yayıncılık.

Thompson, N. H. (1978). Current issues in religious education. Religious Education. 73(6), 611-626.

Westerhoff III, J. H. (1978). Christian education as a theological discipline. SLJT (St. Luke's Journal of Theology), 21(4), 280-288.

Van Ackeren, G. F. (1967). Theology. New Catholic Encyclopedia, 14, 39-49. 
Extended Abstract

\section{The Place of Religious Education Among Sciences: A Study in the Context of James Michael Lee's Approach to Religious Instruction}

Gurbet KIZILTAN, Corresponding Author, Ph. D.

Republic of Turkey National Education Ministry, Bursa / Turkey.

gurbetk@gmail.com

https://orcid.org/0000-0002-5022-2328

Article Type: Research Article

https://doi.org/10.34234/ded.866098

Received Date: 05.07 .2021

Accepted Date: 13.11 .2021

Published Date: 25.12 .2021

\section{Introduction}

Religious education consists of two basic contents (Lee, 1983a, p. 301), religion and education. In terms of its scope, religion is located within the theological sciences whereas education is in the field of social sciences. This multi-content dimension of religious education has caused controversy about which sciences are the right place for religious education. This topic has been discussed in few works dealing with the science of religious education in Turkey (Pazarl, 1967, p. 3, 6; Parladır, 1996, p.13; Bilgin, 2001, p. 1-2; Tosun, 2001, p. 38-57; Aydın, 2017, p. 52, 81, 406), but there are different approaches that emerged after long discussions on the subject in the West. Lee divides these approaches into two: The social science approach and the theological approach (Lee, 1971a ve 1973a). The aim of this study is to reveal the theoretical framework of the social science approach from Lee's perspective, and thus to seek an answer to the question of which science religious education should be in. 


\section{Lee's Religious Instruction Approach}

The theological religious education paradigm prevailed in Christian religious education until the 1960s (Newell, 2004, p. 22). However, II. The Vatican Council made a revolution by emphasizing the importance of utilizing social science data in religious education (Hobson and Welbourne, 2002, p. 55-58). Lee's approach is actually part of this revolution (Lee, 1972a, p. 10).

Lee revealed his approach in his three-volume works called trilogy, which he published between 1971-1985 (Lee, 1971a, 1973a, 1985b). In these works, Lee argues that religious education is ontologically a different field from theology (Lee, 1976, p. 253), therefore it is not a theological but a social scientific discipline (Lee, 1982, s. 122 and 1996, s. 45).

The distinctive feature of Lee's approach is that it adheres to empirical, objective, and quantitative social science methodology and basic principles (Lee, 1971a, p.184-216; Coughlin, 1981, p. 131), and understand, explains, and predicts religious behaviors based on empirical data (Burgess, 1975, p. 127-128).

\section{Main concepts in Lee's approach}

At the center of Lee's approach are the concepts of religion, teaching/instruction, learning, and behavior. According to Lee's operational definition, religion is a holistic lifestyle that expresses the entire relationship a person has with God (Lee, 2000, p. 256). Pointing out that religion is a purely human activity with this definition (Lee, 1985a, p. 21 and 1985b, p. 650), Lee also defines teaching in terms of learning. Teaching is facilitating learning (Lee, 1973a, p. 57) and leading to behavior change (Lee, 1978a, p. 40; Burgess, 1996, p. 212). Behavior is a broad concept that includes both overt physical actions and internal activities (Lee, 1971a, p. 55).

Based on research data (Goldman, 1964, p. 1-9), Lee states that religious learning is not different from other types of learning (Lee, 1978a, p. 50), and social sciences contribute to religious education by discovering the basic principles of the nature of teaching-learning(Lee, 1988a, p. 166-167), but the theological approach that relegates religious learning to the Holy Spirit ignores learning laws (Lee, 1973a, p. 150 ve 1996, p. 55).

According to Lee, teaching which is synonym with instruction that structures educational processes for desired learning outcomes (Lee, 1971a, s. 8), is an 
experimental activity, a science-art (Lee, 2000, p. 253) based on scientific data, laws, and theories (Lee, 1993a, p. 33). Teaching as science has three functions: explanation (Lee, 1992, p. 168-169 and 1993b, p. 190), prediction (Lee, 1972b, p. 43-54), and verification of teaching activity (Lee, 1971a,p. 121-122).

\section{The nature of religious instruction}

Lee's theory focuses on religious instruction rather than the broader concept of religious education (Lee, 1988c, p. 34). With this term, Lee directs his attention to the controllable factors that lead to religious behavior (Newell, 2004, p. 27) because instruction refers to planned education (Lee, 1983b, p. 2).

Religious instruction is a scientific and artistic activity based on the science of teaching-learning (Lee, 1978a, p. 42 ), a facilitation process that brings about a change in behavior in the direction of religion (Burgess, 1996, p. 20; Lee, 1970a, p. 12).

Religious instruction has important focal points: Experience (Cullen, 2005, p. 174), and Christian life (Burgess, 1974, p. 296, which expresses the religious dimension of life and consists of five dimensions (Glock, 1962, p. 98-110; Lee, 1971a, p. 56, 212-213).

In the religious instruction process, there are six basic variables: Student as an individual in the center and target of religious instruction (Lee, 1963, p. 111143 ), aim (Lee, 1978a, p. 53), subject-matter (Lee, 1982, p. 132), teacher (Lee, 1995, p. 554), learning environment (Lee, 1985a, p. 34), and evaluation (Lee, 1978 b, p. 28). The approach that includes these basic variables and explain, predict and verify the relationship between them is the most appropriate approach for teaching religion (Lee, 1996, p. 49).

\section{The content of religious instruction}

The religious instruction consists of two basic contents (Lee, 1985b, p. 8): Religion which is called substantive content and instruction which is called structural content. Religion is the learning subject of religious instruction; structural content refers to the religious instruction practice (Lee, 1988a, p. 153).

The structural content of religious instruction. According to Lee's taxonomy, religious instruction has six structural contents from general to specific (Lee, 1972c, p. 369): Approach (Lee, 1971a, p. 33), style (Lee, 1983b, p. 36), strategy (Lee, 1977, p. 131), method, technic, and step (Lee, 1992, p. 197-199). 
The substantive content of religious instruction. Lee, based on empirical research data defines nine substantive contents; product content (Lee, 1992, p. 173; Baatuma, 1986, p. 174), process content (Lee, 1978b, p. 22), cognitive content (Lee, 1987a, p. 51), affective content (Lee, 1985b, p. 196; Cullen, 2005, p. 179), verbal content (Lee, 1970b, p. 81), nonverbal content, unconscious-conscious content, and lifestyle content (Lee, 1985b, p. 276-277, 475-484, 608$612,629)$. Religion, which is the substantive content of religious instruction, takes on many and different forms depending on the importance and order of these sub-contents (Lee, 1982, p. 116).

\section{Methodology and Main Arguments of the Theological Approach}

To determine whether religious instruction is a form of social science or theology, it is important to know the nature of theology and the methodology of theological science.

Theology, introduced to Christian literature by St. Thomas (Van Ackeren, 1967, p. 39), means the science of God as an academic discipline (Little, 1990, p. 649). According to Lee, theology is a cognitive study that uses reason and divine revelation (Lee, 1971a, p. 103-104) to systematically explore and explain God and His actions (Lee, 2000, p. 256), a field of study that deals with God and His relationship to the universe (Lee, 1971a, p. 103-104).

\section{The methodology of theological science}

As a verification method; theological science, which uses the scripture, the magisterium, tradition, faith, and natural logic (Lee, 1971a, p. 122), is fundamentally different from the sciences that theologians call profane sciences (Allen, 2017, p. 417-433; Hick, 1960, p. 12-31; Ommen, 1979, p. 357-384). Theological science, which includes personal and mystical elements, is methodologically speculative and supernatural (Knudsen, 1966, p. 158-159). In the social sciences, the verification of propositions is based on the controlled observation and experimental testing of facts and relationships (Lee, 1971a, p. 128, 159-89).

\section{Religious education as a theological discipline}

Theological macro theory conceptualizes religious education as a branch of practical theology (Thompson, 1978, p. 614-615) and argues that theology is the determining norm of religious education (Miller, 1950; Knox, 1976, p. 6; 
Westerhoff III, 1978, p. 284-285), that is, it has the power to explain, predict and verify all dimensions of religious education (Lee, 1982, p. 122). Lee argues that religious instruction has a unique ontological existence of its own (Lee, 1973b, p. 282), not a branch of practical theology, and therefore not a theological discipline (Lee, 1996, p. 47).

\section{Social Scientific Religious Instruction's Relationship with Theology}

Lee states that theology has a key role in the substantive content of religious instruction, but in no way can it be the determining norm of it (Lee, 1971a, p. 246). He argues that theology has two basic roles in religious instruction, internal and external (Lee, 2000, p. 257). Theology fulfills its internal role when it is a dimension of the substantive content of religious instruction, namely religion (Savage, 1990, p. 27). According to Lee, theology fulfills its external role when it reflects on the theological meaning of religious instruction (1982, p. 155156). Accordingly, theology plays no role in the structural content of religious instruction (Lee, 1978a, p. 50-54).

\section{Conclusion}

Lee, who keeps religious instruction outside the boundaries of theology and positions it as a social scientific discipline, states that the essence of religious education is teaching. Teaching, which is an experimental activity, is the work of social science, not of theology, which is cognitive science. The theological macro theory, which relegates religious learning to the Holy Spirit and thus distinguishes it from other types of learning, neglects the laws of learning and cannot explain how learning occurs. In addition, theological science, which is based on the word of God, faith, or magisterium as a method of verification, is methodologically speculative. Because it contains personal and mystical elements, thus making sound empirical knowledge impossible. Therefore, theology cannot be the appropriate macro theory for the religious instruction, which is an empirical research area. 
Etik Beyan / Ethical Statement: Bu çalı̧̧manın hazırlanma sürecinde bilimsel ve etik ilkelere uyulduğu ve yararlanılan tüm çalışmaların kaynakçada belirtildiği beyan olunur. / It is declared that scientific and ethical principles have been followed while carrying out and writing this study and that all the soruces used have been properly cited.

Finansman / Funding: Yazar bu araştırma için TÜBİTAK'tan finansman desteği aldığını kabul eder. / The author acknowledges that he received financial support from TÜBITAK for this research. 